\title{
Geomicrobiological processes in extreme environments: A review
}

\author{
1 Geomicrobiology Laboratory, China University of Geosciences, Beijing, 100083, China. \\ 2 Department of Geology, Miami University, Oxford, OH, 45056, USA. Email: dongh@muohio.edu \\ 3 School of Earth Sciences, China University of Geosciences, Beijing, 100083, China.
}

\begin{abstract}
The last decade has seen an extraordinary growth of Geomicrobiology. Microorganisms have been studied in numerous extreme environments on Earth, ranging from crystalline rocks from the deep subsurface, ancient sedimentary rocks and hypersaline lakes, to dry deserts and deep-ocean hydrothermal vent systems. In light of this recent progress, we review several currently active research frontiers: deep continental subsurface microbiology, microbial ecology in saline lakes, microbial formation of dolomite, geomicrobiology in dry deserts, fossil DNA and its use in recovery of paleoenvironmental conditions, and geomicrobiology of oceans. Throughout this article we emphasize geomicrobiological processes in these extreme environments.
\end{abstract}

\section{Introduction}

The last decade has seen an extraordinary growth of Geomicrobiology. Microorganisms have been studied in numerous extreme environments on Earth, ranging from crystalline rocks from the deep subsurface, ancient sedimentary rocks, hypersaline lakes, to dry deserts and deep-ocean hydrothermal vent systems. Even signatures of possible ancient life on Mars are being presented. Studies of mineral-microbe interactions lie at the heart of this interdisciplinary field, as minerals and rocks are the most fundamental earth materials with which microbes interact at all scales. Below is a short review of certain topics. Because of the diversity of the topics and rapid development in this area, it is impossible to cover all aspects adequately. We hope that this review will promote more focused research in Geomicrobiology, and encourage collaboration among geologists, geochemists, soil scientists, microbiologists, and environmental engineers.

\section{Continental deep-subsurface research}

Investigations of geomicrobiological processes in the continental deep subsurface are driven by a number of theoretical and practical reasons. The theoretical reasons include our curiosity about the origin of life and possible presence of life on other planets such as Mars. On the practical side, microorganisms isolated from the deep subsurface often contain unique assets, and they are ideal for environmental bioremediation, microbially enhanced oil recovery, and biotechnology development. The conditions of the deep continental subsurface are typically represented by anaerobic conditions, high or low $\mathrm{pH}$, high temperature and pressure, high radiation (from decay of radioactive elements), and high salinity (Rothschild and Mancinelli, 2001). These unique conditions have selected unique microorganisms and novel metabolic functions. Readers are directed to recent review papers (Kieft and Phelps, 1997; Pedersen, 1997; Krumholz, 2000; Pedersen, 2000; Rothschild and Mancinelli, 2001; Amend and Teske, 2005; Fredrickson and Balkwill, 2006). A recent study suggests the importance of pressure in the origination of life and biomolecules (Sharma et al., 2002). In this short review and in light of some most recent developments, we focus on two specific aspects: novel metabolic functions and energy sources.

\section{Some metabolic functions of continental subsurface microorganisms}

Because of the unique geochemical, hydrological, and geological conditions of the deep subsurface, microorganisms from these environments are different from surface organisms in their metabolic traits. Our understanding of these organisms and their metabolic functions are hampered by the difficulty of cultivation. This difficulty is due to multiple, the subsurface conditions to grow microorganisms in laboratory and their slow growth rate is a major one. Nonetheless, our current knowledge based on culture-independent approach, limited success in cultivation, and isotopic evidence, suggests that the subsurface microorganisms are often anaerobic and thermophilic chemolithotrophs that are distinctly different from surface organisms. Some organisms have shown remarkable resistance to radiation (Pitonzo et al., 1999; DeFlaun et al., 2007). There are generally three categories of continental subsurface environments: subsurface aquifers and/or hydrothermal waters; sedimentary basins/oil reservoirs, and crystalline metamorphic/igneous rocks. Below is a summary of several major metabolic processes that occur in these environments.

\section{Metal reduction by thermophilic microorganisms}

Metal reduction by thermophilic organisms is of great interest for a number of reasons. First, hydrothermal systems are often considered as modern analogs of the ancient Earth's biosphere, and $\mathrm{Fe}(\mathrm{III})$ reduction could have been an important process on early Earth (Vargas et al., 1998). Second, metal-microbe interaction is relevant as we search for life on other planets, as magnetite, a product of microbial reduction of iron, may constitute a robust biomarker that may have survived through later stages of alteration (Nealson and Cox, 2002). Third, metal reduction by thermophilic organisms is intimately connected to human life, such as bioremediation of heavy metals and radionuclides in abandoned nuclear facilities and landfill sites.

Thermophilic metal reducers are present in virtually all possible habitats, ranging from sedimentary basins (oil reservoirs), terrestrial hydrothermal waters, to deep subsurface crystalline rocks. Thermophilic metal reducers are widely distributed in 15 bacterial and 4 archaeal genera, and most of them are only capable of reducing $\mathrm{Fe}(\mathrm{III})$ in either aqueous or chelated form, with a few being able to reduce crystalline iron oxides (Slobodkin et al., 2005). Magnetite 
and siderite are common products depending on environmental conditions. Heterotrophy is a dominant metabolic pathway with a few organisms capable of autotrophic growth coupled with iron reduction. Interested readers are strongly advisted to refer to a review paper (Slobodkin et al., 2005). Recently, a new anaerobic, thermophilic, facultatively chemolithoautotrophic bacterium has been isolated from terrestrial hydrothermal springs that are capable of dissimilatory $\mathrm{Fe}(\mathrm{III})$ reduction (Zavarzina et al., 2007). Thermincola ferriacetica (Isolate Z-0001) is able to grow chemolithoautotrophically with molecular hydrogen as the only energy substrate, Fe(III) as electron acceptor and $\mathrm{CO}_{2}$ as the carbon source (Zavarzina et al., 2007). Strain Z-0001T is the first thermophilic bacterium capable of both dissimilatory iron reduction and the anaerobic growth on $\mathrm{CO}$, coupled with hydrogen formation.

One interesting feature with certain thermophilic, acidophilic metal reducers is the ability to conserve energy from both $\mathrm{Fe}$ (III) reduction and $\mathrm{Fe}(\mathrm{II})$ oxidation (Acidimicrobium ferrooxidans, Sulfobacillus thermosulfidooxidans, Sulfobacillus acidophilus) (Bridge and Johnson, 1998). These organisms are capable of iron redox cycling when they are grown in batch cultures at atmospheric partial $\mathrm{O}_{2}$ pressure. Zhang et al. (unpublished data) recently observed iron cycling with a neutrophilic thermophile (Figure 1). Initially, it was thought that iron redox cycling was carried out by an enrichment culture. However, iron cycling persisted after multiple transfers and isolation. The reduction of $\mathrm{Fe}$ (III) in iron oxides and clay minerals and oxidation of $\mathrm{Fe}$ (II) in iron sulfides operated at different $\mathrm{pH}$ conditions, with slightly acidic $\mathrm{pH}$ favoring $\mathrm{Fe}(\mathrm{III})$ reduction and alkaline $\mathrm{pH}$ favoring $\mathrm{Fe}$ (II) oxidation. Lactate served as an electron donor during $\mathrm{Fe}(\mathrm{III})$ reduction, and acetate was believed to be the electron acceptor during $\mathrm{Fe}(\mathrm{II})$ oxidation. Molecular analysis identified a single organism (Thermoanaerobacter ethanolicus) responsible for both $\mathrm{Fe}(\mathrm{III})$ reduction and $\mathrm{Fe}(\mathrm{II})$ oxidation. A previous paper reports that acetate is necessary during $\mathrm{Fe}(\mathrm{II})$ oxidation (Kappler and Newman, 2004).
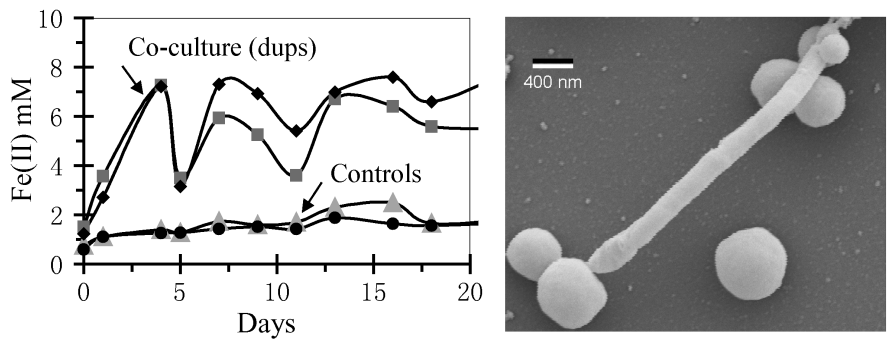

Figure 1 Left: $0.5 \mathrm{~N} \mathrm{HCl}$ extractable $\mathrm{Fe}(\mathrm{II})$ with time showing Fe reduction-oxidation cycles in clay mineral nontronite $(23.4 \%$ structural Fe (III)) inoculated with a co-culture (mixture of rods and cocci) at $\mathrm{pH}$ 9.5. The no-cell controls do not show significant change in Fe(II) concentration. Right: SEM image showing a close association between rod-shaped and coccusshaped cells. The scale bar is $400 \mathrm{~nm}$. From Zhang et al. (unpublished data).

\section{Organic carbon degradation by heterotrophic and fermenta- tive organisms}

In petroleum reservoirs or groundwater aquifers within sedimentary rocks, because of the availability of abundant organic matter, subsurface organisms are generally characterized by organotrophic thermophiles/hyperthermophiles (Miroshnichenko and Bonch-Osmolovskaya, 2006). Magot et al. (2004) and Van Hamme (2003) reviewed the current state of knowledge of microorganisms from petroleum reservoirs, including mesophilic and thermophilic sulfate-reducing bacteria (SRB), methanogens, mesophilic and thermophilic fermentative bacteria, and iron-reducing bacteria. Many of these organisms can degrade sedimentary organic carbon (McMahon and Chapelle, 1991; Krumholz et al., 1997) and oil components as energy and carbon sources. Among major groups of organisms iden- tified in these environments (Thermoanaerobacter, Thermodesulfovibrio, Thermotoga, Thermococcus, Methanothermobacter, Methanococcus, and Methanobacterium) (Nazina et al., 2000; Orphan et al., 2000), SRB (Amend and Teske, 2005) and methanogenic archaea are of special importance. Thermophilic SRB are mainly various species of Desulfotomaculum, Thermodesulforhabdus, and Desulfacinum (Amend and Teske, 2005). In petroleum reservoirs, abundant organic compounds provide growth substrates for these heterotrophic sulfate reducers. In a recent study, Cai et al. (2007) reported that SRB are capable of coupling U(VI) reduction with oxidation of petroleum with implication for a microbial role in $\mathrm{U}$ ore deposit formation in the Shashadetai deposit, the northern Ordos basin, NW China.

In sedimentary basins without petroleum potential, these organisms, which live in highly-permeable sandstones, actually depend on organic materials from adjacent shales for growth (Krumholz et al., 1997; 1999). The interface between aquifer (high permeability) and aquitard (low permeability) appears to be the most important location for a number of biogeochemical reactions including sulfate reduction (McMahon, 2001). More recently, a new anaerobic, thermophilic, facultatively chemolithoautotrophic bacterium was isolated from terrestrial hydrothermal springs (Zavarzina et al., 2007) This organism is capable of dissimilatory Fe (III) reduction.

\section{Sulfur oxidation}

In geothermal vents, solfataras, and hot springs, reduced sulfur compounds may be more important electron donors than organic carbon compounds, as these environments often contain high concentrations of inorganic compounds such as $\mathrm{CO}_{2}, \mathrm{SO}_{2}, \mathrm{~N}_{2}, \mathrm{CO}, \mathrm{H}_{2}$, nitrate, and various metal oxides and sulfides $\left(\mathrm{H}_{2} \mathrm{~S}\right)$. As a result, the primary production of biomass in these environments is energized by chemolithoautotrophic redox reactions of these inorganic compounds. Synthesized biomass may be oxidized by heterotrophic organisms. Among chemolithoautotrophs, oxidizers of sulfur compounds coupled with reduction of nitrate and oxygen are commonly isolated (Aragno, 1992; Skirnisdottir et al., 2001; Takai et al., 2001; Franca et al., 2006) in these niches, as elemental sulfur and sulfur compounds can serve as both electron acceptors and donors and are used by a number of microorganisms to support growth.

The pathways and biochemistry of thermophilic, sulfur-oxidizing prokaryotes have been recently reviewed (Friedrich et al., 2005; Kletzin et al., 2004). Most archaeal sulfur oxidizers are aerobic or facultatively anaerobic, chemolithoautotrophic, thermoacidophilic, with Acidianus ambivalens, A. infernos, and A. brierleyi from the Sulfolobales order of the Crenarchaeota kingdom as representative organisms. Some of the Sulfolobales are facultative anaerobes growing either by hydrogen oxidation with $\mathrm{S}_{0}$ as electron acceptor, forming $\mathrm{H}_{2} \mathrm{~S}$, or by $\mathrm{S}_{0}$ oxidation with oxygen, forming sulfuric acid. In the sulfur-oxidizing organisms, the cytoplasmic sulfur oxygenase reductase (SOR) catalyzes the conversion of sulfur in the presence of $\mathrm{O}_{2}$ to give sulfite, thiosulfate and hydrogen sulfide as products (Friedrich et al., 2005).

Because geothermal fields are commonly rich in inorganic reduced sulfur compounds, they are particularly suited to thermophilic sulfur-oxidizing bacteria (Aragno, 1992; Friedrich, 1998; Ehrlich, 2005). However, relatively few thermophilic sulfur-oxidizing bacterial species have been isolated. Aragno (1992) divides sulfur-oxidizing thermophiles in the domain Bacteria into four main categories according to their metabolism. The first group contains hydrogen- and sulfur-oxidizing bacteria. Among this group are obligate chemolithoautotrophic bacteria in the AquifexHydrogenobacter group and the spore-forming facultative chemolithoautotroph Bacillus schlegelii. The second group contains two Thermothrix species, strictly thermophilic sulfur oxidizers. The third category includes moderately thermophilic, acidophilic Thiobacillus-like bacteria. The fourth category includes moderately thermophilic, strongly acidophilic sulfur- and iron-oxidizing bacteria (Aragno, 1992). Chemolitho-autotrophic sulfur bacteria are phylogenetically and physiologically diverse and are 
alkaliphilic (Sorokin et al., 2003; Banciu et al., 2005), neutrophilic or acidophilic (Kelly et al., 1997; Friedrich, 1998; Friedrich et al., 2001).

A recent study isolated the first facultatively mixotrophic sulfur-oxidizing Thermus strain from a sulfide-rich hot spring in Iceland (Skirnisdottir et al., 2001), although various species of Thermus are most commonly obtained in this environment (Hreggvidsson et al., 2006). Certain Thermus strains from terrestrial geothermal environments are capable of oxidizing arsenite to arsenate (Gihring and Banfield, 2001; Gihring et al., 2001). However, they do not conserve energy from oxidation of sulfur compounds. Sulfur-oxidizers are not limited to hydrothermal environments. For example, a sulfur-oxidizing chemolithotroph was isolated from underground crude-oil storage cavaties, suggesting that a group of bacteria (called cluster I bacteria) could yield energy for growth by oxidizing petroleum sulfur compounds (Kodama et al., 2003).

\section{Energy source}

The extent of deep continental subsurface microbial life is ultimately controlled by whether sufficient energy exists to sustain a minimal metabolism. Chemolithotrophic communities depend on geochemical energies for growth. $\mathrm{H}_{2}$ is the most abundant source (Stevens and McKinley, 1995; Pedersen, 2001; Chapelle et al., 2002) and a variety of organisms can use $\mathrm{H}_{2}$, including nitrate reducers, $\mathrm{Mn}$ (III) and $\mathrm{Fe}(\mathrm{III})$ reducers, sulfate reducers, and methanogens. A substantial amount of energy is generated when $\mathrm{H}_{2}$ oxidation is coupled with these various electron acceptors (Amend and Teske, 2005). The high diffusivity of $\mathrm{H}_{2}$ makes it readily available to microorganisms in confined pore spaces in deep subsurfaces.

Subsurface $\mathrm{H}_{2}$ can be produced via multiple pathways. The first one is thermal decomposition of organic matter. The second one is via organic matter fermentation (Chapelle, 2000). The third pathway is via reactions between ultramafic and mafic rocks and fluids that circulate them (commonly water), a process called serpentinization. Recent years have seen an increased interest in studying the serpentinization process. This process can produce strongly reducing conditions and high $\mathrm{H}_{2}$ concentrations. The $\mathrm{H}_{2}, \mathrm{CH}_{4}$, and other reduced compounds generated during this process may represent a substantial and widespread source of chemical energy for carbon fixation by autotrophic microbial communities in both surface and subsurface environments (Stevens and McKinley, 1995; Alt and Shanks, 1998; Charlou et al., 1998; Kelley et al., 2001; Chapelle et al., 2002; Charlou et al., 2002; Sleep et al., 2004; Kelley et al., 2005; Nealson et al., 2005). Because such ecosystems exist with no input from photosynthesis, they could represent a significant source of primary biomass production in the subsurface. Such communities may be modern analogs of ancient communities that were present on the early Earth or exist on Mars and Europa (Shock, 1997; Holm and Andersson, 1998; Fisk and Giovannoni, 1999; McCollom et al., 1999; Sleep et al., 2004; Zolotov and Shock, 2004). Because of the abundance of both $\mathrm{H}_{2}$ and $\mathrm{CO}_{2}$ during this serpentinization process, methanogens are usually the dominant organisms in the community (Stevens and McKinley, 1995; Chapelle et al., 2002; Takai et al., 2004).

The strongly reducing conditions developed during serpentinization are also favorable environments for the abiotic synthesis of methane and other organic compounds from the reduction of $\mathrm{CO}_{2}$, suggesting that serpentinites and the fluids discharging from them could be enriched in abiotic organic compounds (Abrajano et al., 1990; Charlou and Donval, 1993; Berndt et al., 1996; Charlou et al., 1998; Holm and Andersson, 1998; Shock and Schulte, 1998; Horita and Berndt, 1999; Holm and Charlou, 2001; McCollom and Seewald, 2001; Charlou et al., 2002; McCollom and Seewald, 2003, 2006). Abiotically produced organic compounds are additional chemical energy for microorganisms in subsurface and hydrothermal environments, and may have been a primary source of prebiotic compounds during the early evolution of life (Shock, 1990; Holm and Andersson, 1998; Russell et al., 1998; Shock and Schulte, 1998; Russell, 2003). A variety of heterotrophic organisms could depend on abiotically synthesized organic compounds.
A few recent studies have strongly demonstrated the fourth pathway for $\mathrm{H}_{2}$ generation in the continental subsurface, i.e., radiolytic $\mathrm{H}_{2}$ production. In this pathway, $\mathrm{H}_{2}$ is produced by radiolytic dissociation of $\mathrm{H}_{2} \mathrm{O}$ during radioactive decay of $\mathrm{U}$, Th, and $\mathrm{K}$ in the host rock (Lin et al., 2005). This radiolytic $\mathrm{H}_{2}$ is consumed by methanogens and abiotic hydrocarbon synthesis. Lin et al. (2005) has demonstrated that this abiotic source of $\mathrm{H}_{2}$ is sufficient to account for high concentrations of $\mathrm{H}_{2}$, and to sustain the lithoautotrophic communities detected in fracture water of the deep mines of South Africa (Lin et al., 2007). Analysis of gases in crystalline igneous rocks from Canada and South Africa (Ward et al., 2004; Lollar et al., 2006) has shown that these gases are composed predominantly of $\mathrm{H}_{2}$ and $\mathrm{CH}_{4}$ with smaller fractions of light hydrocarbons. The isotopic and chemical composition appears to suggest that they are a mixture of abiotic hydrocarbons and biotic $\mathrm{CH}_{4}$ produced from methanogenic microbes utilizing the $\mathrm{H}_{2}$ present. In such settings, radiolytic $\mathrm{H}_{2}$ may be the predominant source powering the deep subsurface microbial communities (Lin et al., 2005; 2007).

\section{Saline environments}

Saline environments are globally distributed on Earth (Oren, 2002a) and they are considered extreme environments for microbial life (Oren, 1999a). Halophiles thrive in hypersaline niches and include prokaryotes and eukaryotes (DasSarma and Arora, 2001). Among halophilic microorganisms are found a variety of heterotrophic and methanogenic archaea; photosynthetic, lithotrophic, and heterotrophic bacteria; and photosynthetic and heterotrophic eukaryotes. Halophilic microorganisms occur in various sizes, shapes, and colors (Vreeland and Hochstein, 1993; Oren, 1999b) (Figure 2). Readers are directed to recent books on microbiology and biochemistry of halophiles (Oren, 1999a; Ventosa, 2004).

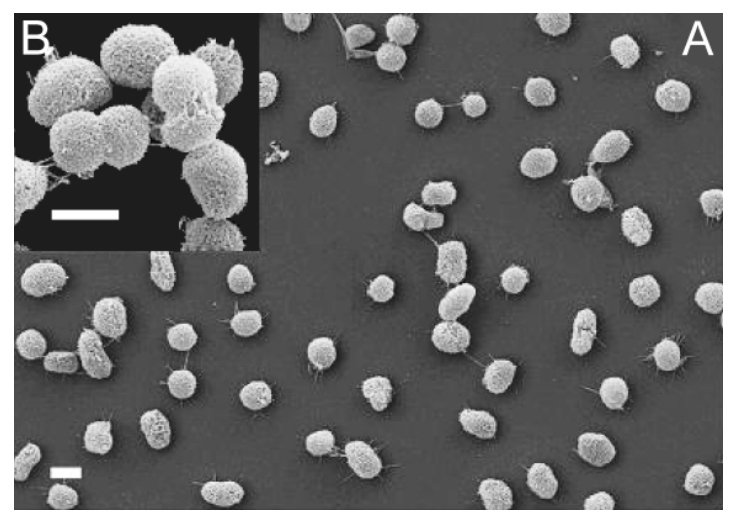

Figure 2 SEM secondary electron image of a halophilic archaeal isolate. The scale bar is $2 \mu \mathrm{m}$.

\section{Effect of salinity on microbial composition}

Previous studies have shown that the taxonomic diversity of microbial populations in saline and hypersaline environments is low (DasSarma and Arora, 2001; Oren, 2001; Benlloch et al., 2002), consistent with general ecological principles that more extreme environments are inhabited by less diverse communities (Frontier, 1985). In general, microbial composition is primarily controlled by salinity (Oren, 2002b; Wu et al., 2006). Wu et al. (2006) studied the bacterioplankton (free-living) community composition along a salinity gradient of high-mountain lakes located on the Tibetan Plateau, China, and reported a succession of proteobacterial groups as a function of salinity. In general, the relative abundance of the Alphaproteobacteria and the Gammaproteobacteria increases, but the Betaproteobacteria decreases with increasing salinity. This observation is consistent with many other studies on inland waters (Glockner et al., 1999; 
Bockelmann et al., 2000; Brummer et al., 2004), dynamic saline systems such as estuaries (Bouvier and del Giorgio, 2002; del Giorgio and Bouvier, 2002; Cottrell and Kirchman, 2003; Kirchman et al., 2005; Henriques et al., 2006; Zhang et al., 2006) and coastal solar salterns (Benlloch et al., 2002). Henriques et al. (2006) examined successions of multiple groups of bacteria and reported dominance of the Alphaproteobacteria and Gammaproteobacteria in the marine-brackish section of the Ria de Aveiro estuary (Portugal) and the Betaproteobacteria, the Deltaproteobacteria and the Epsilonproteobacteria in the freshwater section of the estuary. The reasons for such succession have been suggested to be related to cell inactivation/death due to dynamic hydrological conditions such as mixing of riverine and estuarine waters (Bouvier and del Giorgio, 2002), but observed successions in stable water bodies appear to suggest that dynamic mixing is not necessarily a pre-condition (Wu et al., 2006). Other studies have shown different succession patterns with salinity. For example, Langenheder et al. (2003) showed that Alpha- and Betaproteobacteria, and Gammaproteobacteria were more abundant under freshwater conditions. Bernhard et al. (2005) analyzed bacterioplankton community structure in Tillamook Bay, Oregon and its tributaries to evaluate phylogenetic variability and its relation to changes in environmental conditions along an esturine gradient. The authors observed that the Gammaproteobacteria and Betaproteobacteria and members of the Bacteroidetes dominated in freshwater samples, while the Alphaproteobacteria, Cyanobacteria and chloroplast genes dominated in marine samples. When bacteria are attached to solid particles, such successions are generally not observed (Selje and Simon, 2003; Jiang et al., 2007). In general, particle-attached and free-living bacterial community composition is fundamentally different (DeLong et al., 1993; Crump et al., 1999; Schweitzer et al., 2001; Acinas et al., 2005: Phillips et al., 1999).

\section{Strategy of microbial adaptation to high salinity}

With increasing salinity, bacterial abundance decreases, but archaeal abundance may increase (Jiang et al., 2007b), so that archaea become predominant in high-salinity environments (Maturrano et al., 2006). The reason for differential response of bacteria and archaea to increased salinity is their different salt tolerance levels. Most halophilic bacteria can live at moderate salinity up to $2.5 \mathrm{M}$ salt concentrations (Ventosa, 1998), but halophilic archaea can survive up to salt saturation. Because of their different requirements for salt, halophilic bacteria and archaea tend to occupy different salinity niches, with the former being dominant at low salinity and the latter being dominant at high salinity (Oren, 1993). However, most halophilic species exist and function within a range of salinity. Within this range, adaptation to increase in salinity is achieved in different ways. The first (and the most important) one involves the accumulation of organic compatible solutes within cytoplasm without the need for change of intracellular proteins (thus called compatible). This mechanism, referred to as "organic-osmolyte strategy", is widespread among the domain Bacteria and Eukarya and some methanogenic Archaea. The major solutes are the amino acid-derivatives glycine-betaine and ectoine (Galinski and Truper, 1994). The genes encoding the enzymes for biosynthesis of these solutes have been isolated and sequenced. The second adaptation mechanism is the intracellular accumulation of a high concentration of $\mathrm{K}^{+}$. This strategy, referred to as "salt-in-cytoplasm strategy", requires extensive adaptation of the intracellular enzymatic machinery, and is therefore energetically expensive. This mechanism is used by a minority of the known halophiles, including Halobacteriales of the domain Archaea and Haloanaerobiales of the domain Bacteria.

\section{Metabolic processes in saline environments}

There are a variety of metabolic processes in saline environments (Oren, 2001). Here we summarize some recent findings through a few examples.

\section{Ammonia oxidation}

Ammonia-oxidizing bacteria (AOB) are chemolithoautotrophs that use ammonia as the sole energy source and carbon dioxide as the carbon source. AOB catalyze the "nitrification process" $\left(\mathrm{NH}_{3} \rightarrow \mathrm{NO}_{2}{ }^{-} \rightarrow \mathrm{NO}_{3}{ }^{-}\right)$, which has a key position in natural nitrogen cycling. Ammonia oxidation takes place either aerobically or anaerobically. Different AOB tend to occupy different environmental niches and respond to environmental changes (ammonium concentration, $\mathrm{pH}$, redox state, and salinity) in different ways (Prosser and Embley, 2002). In estuarine and coastal environments, AOB respond to a freshwater-marine salinity gradient and nitrogen inputs (among others) through changes in community composition and abundance (Francis et al., 2003; Freitag et al., 2006; Urakawa et al., 2006).

Energetic considerations suggest that aerobic autotrophic ammonia oxidation is not a favorable process in highly saline environments, because nitrifying bacteria gain little energy from oxidation of ammonium and nitrite, and a large fraction of generated energy will have to be used to produce the NADPH required for autotrophic $\mathrm{CO}_{2}$ reduction (Oren, 2001). Oren (2001) estimated that ammonia oxidation can exist at a salinity up to $\sim 16 \%$. Indeed, culture characteristics (Koops et al., 2004) and some molecular results (Joye et al., 1999; Ward et al., 2000) are consistent with this observation. However, some studies have detected various AOB in more saline environments (Voytek et al., 1999; Benlloch et al., 2002; Stougaard et al., 2002), although the rates of primary production and nutrient uptake are generally reduced at increased salinity (Joint et al., 2002).

Recent studies have discovered that ammonia oxidation can be carried out by non-thermophilic Crenarchaeota (Venter et al., 2004; Francis et al., 2005; Konneke et al., 2005; Schleper et al., 2005; Treusch et al., 2005; Nicol and Schleper, 2006) in a diverse range of environments, including marine and freshwater sediments, soils, and tissues and digestive tracts of animals (Leininger et al., 2006; Nicol and Schleper, 2006; He et al., 2007; Zhang et al., 2007). Further studies have shown that ammonia oxidizing archaea are more abundant than their bacterial counterparts in certain soils (Leininger et al., 2006; He et al., 2007) and oceans (Wuchter et al., 2006), suggesting that in certain environments AOA may play a more important role than AOB in global nitrogen cycling. The presence of AOA in saline environments has not been reported. Based on the current knowledge that AOA are limited to Crenarchaeota and Crenarchaeota are generally absent in high salinity environments (Cytryn et al., 2000; Benlloch et al., 2002; Demergasso et al., 2004; Maturrano et al., 2006; Jiang et al., 2007), AOA may not be present in those environments. However, a recent study recovered Crenarchaeota from a very saline soil (13\% salinity) (Walsh et al., 2005), suggesting that non-thermophilic Crenarchaeota, perhaps even AOA, may be present in saline environments. Indeed, Jiang et al. (unpublished data) detected AOA in Qinghai Lake in northwestern China. Likewise, temperature is not a factor in limiting the widespread nature of AOA. Archaeal amoA genes have been recovered in hot springs (Weidler et al., 2007).

\section{Chemolithotrophic oxidation of sulfur compounds}

Although chemolithoautotrophic sulfur-oxidizing bacteria (SOB) have been well studied in acidic (Pronk et al., 1990; Madigan et al., 2004) and neutral environments (Robertson and Kuenen, 1999), the presence of this group in saline environments is not well understood. In the last decade, Sorokin and his co-workers have isolated a large number of haloalkaliphilic SOB functioning at $>9.5$ and inhibiting various saline soda lakes (sodium carbonate/bicarbonate instead of $\mathrm{NaCl}$ ) of varying salinity, mostly in Central Asia (Sorokin and Kuenen, 2005). These authors described three new genera in the Gammaproteobacteria: Thioalkalimicrobium, Thioalkalivibrio, and Thioalkaspira. Many of these species have an optimal $\mathrm{pH}$ of 9-10 and can tolerate total $\mathrm{Na}$ of up to $4.5 \mathrm{M}$. They are capable of autotrophically oxidizing a number of sulfur compounds such as thiosulfate, sulfide, polysulfide, elemental sulfur, and sulfite. While most of these species are 
obligately aerobic, some can oxidize these compounds under microaerophilic and denitrifying conditions. The same authors, also using cultivation-based methods, have isolated a high diversity of moderately and extremely halophilic chemolithoautotrophic SOB in various hypersaline but neutral-pH habitats, including four new genera and representatives of Halothiobacillus and Thiomicrospira (Sorokin et al., 2006b; Sorokin et al., 2006a). The highest $\mathrm{NaCl}$ concentration that some of the species can tolerate is $5 \mathrm{M}$, extending the upper limit of salt tolerance based on bioenergetic considerations (Oren, 2001). Despite these recent advances in isolation and characterization of SOB, quantitative understanding of the importance of these organisms in the overall sulfur cycle is still lacking. Future studies should focus on measurements of rates of sulfur oxidation by various SOB species under in-situ conditions.

\section{Sulfate reduction}

Sulfate-reducing bacteria (SRB) have been shown to use organic solutes (trehalose and glycine betaine) to provide osmotic balance in saline environments (Welsh et al., 1996). This is energetically expensive. In contrast to this demand, little energy is released when acetate is used as an electron donor to couple with sulfate reduction (Oren, 2001). When $\mathrm{H}_{2}$ and lactate are used as electron donors, more energy is released (Oren, 2001). This energy consideration explains why most SRB have an optimal salinity tolerance of no higher than $100 \mathrm{~g} / \mathrm{L}$, although the upper limit may be much higher (Jakobsen et al., 2006; Belyakova et al., 2006). This consideration also explains why isolates obtained from in-situ salinity of $27 \%$ in the northern arm of the Great Salt Lake (Utah) were not able to grow at the in-situ salinity, but optimally at $10 \%$ only (Kjeldsen et al., 2007). In general, the sulfate-reducing rate is inversely correlated with salinity (Brambilla et al., 2001; Sorensen et al., 2004). Kjeldsen et al. (2007) studied the diversity of SRB from an extreme hypersaline sediment, the Great Salt Lake, and demonstrated that the SRB diversity is clustered with the family Desulfohalobiaceae, Desulfobacteraceae, and Desulfovibrionaceae of the class Deltaproteobacteria, and the family Peptococcaceae in the phylum Firmicutes. Not much information is available as yet on the nature of the electron donors used by the communities of SRB in saline environments. A recent paper reported that a wide variety of electron donors (lactate, pyruvate, malate, fumarate, succinate, propionate, butyrate, crotonate, ethanol, alanine, formate, and $\left.\mathrm{H}_{2} / \mathrm{CO}_{2}\right)$ can be used by a moderately halophilic, chemolithoautotrophic $\left(\mathrm{H}_{2} / \mathrm{CO}_{2}\right)$, sulfate-reducing bacterium Desulfovermiculus halophilus (Belyakova et al., 2006).

\section{Biogenic formation of dolomite}

Dolomite, with a chemical composition of $\left[\mathrm{CaMg}\left(\mathrm{CO}_{3}\right)_{2}\right]$ and an ordered structure, is an important mineral both economically and scientifically. The physical and chemical properties of dolomite rocks in sedimentary basins determine the size and quality of oil reservoirs. Dolomite formation plays an important role in global carbon cycling. Sequestration of atmospheric $\mathrm{CO}_{2}$ into dolomite may have contributed to the gradual cooling of the Earth to the extent that life became possible. Dolomite may contain valuable information about the evolutionary history of the Earth.

Despite the economic and scientific importance of dolomite, the mechanism of its formation remains enigmatic. The well-known "dolomite problem" can be stated as follows: dolomite rock is one of the most common sedimentary materials, yet efforts to synthesize dolomite in the laboratory under simulated conditions (i.e., low temperature and pressure) have largely failed (Land, 1998). Dolomite formation is thermodynamically favorable, but kinetically slow, i.e., there exists a kinetic energy barrier in its formation (Krauskopf and Bird, 1995).

Dolomite can form via three pathways, as shown in Table 1.

Geological observations (i.e., poor preservation of fossils, the coarseness of grains, cavities, and pore spaces) indicate that many dolomite rocks form via replacement of pre-existing calcite (i.e.,
Table 1 Possible pathways for dolomite formation.

\begin{tabular}{|c|c|c|c|c|c|}
\hline Dolomite formation mechsanism & $\mathrm{Ca}$ & $\mathrm{Mg}$ & $\mathrm{Sr}$ & $\mathrm{Mg} / \mathrm{Ca}$ & $\mathrm{Sr} / \mathrm{Ca}$ \\
\hline $\mathrm{CaCO}_{3}+\mathrm{Mg}^{2+}+2 \mathrm{HCO}_{3}^{-}->\mathrm{CaMg}\left(\mathrm{CO}_{3}\right)_{2}+\mathrm{CO}_{2}+\mathrm{H}_{2} \mathrm{O}$ & -- & $\downarrow$ & $\uparrow$ & $\downarrow$ & $\uparrow$ \\
\hline $2 \mathrm{CaCO}_{3}+\mathrm{Mg}^{2+}->\mathrm{CaMg}\left(\mathrm{CO}_{3}\right)_{2}+\mathrm{Ca}^{2+}$ & $\uparrow$ & $\downarrow$ & $\downarrow$ & $\downarrow$ & $\downarrow$ \\
\hline $\mathrm{Ca}^{2+}+\mathrm{Mg}^{2+}+4 \mathrm{HCO}_{3}^{-}->\mathrm{CaMg}\left(\mathrm{CO}_{3}\right)_{2}+2 \mathrm{CO}_{2}+2 \mathrm{H}_{2} \mathrm{O}$ & $\downarrow$ & $\downarrow$ & $\downarrow$ & $\uparrow$ & $\uparrow$ \\
\hline
\end{tabular}

$\uparrow=$ increases in concentration, $l=$ decreases in concentration. $---=$ no change in concentration. (After Rodriguez et al., 2000).

pathway $1 \& 2$ ) over a long time under conditions of high salinity and $\mathrm{pH}$, a low $\mathrm{Ca} / \mathrm{Mg}$ ratio, and an elevated temperature (Krauskopf and Bird, 1995). Dolomite can also form via primary precipitation (pathway 3), especially those dolomites that are associated with saline evaporite deposits (Vasconcelos and McKenzie, 1997; Wright, 1999) and methane-bearing sediments and gas hydrates on the ocean floor (Baker and Burns, 1985; Cavagna et al., 1999; Rodriguez et al., 2000; Pierre and Rouchy, 2004; Sassen et al., 2004). However, neither the replacement nor direct precipitation mechanism has been demonstrated in the laboratory at low temperatures in the absence of microbial activity.

The recent discovery of microbially mediated dolomite formation in culture experiments with sulfat- reducing bacteria (SRB) suggests that bacteria can overcome the kinetic energy barrier to dolomite formation by increasing $\mathrm{pH}$ and carbonate alkalinity (Vasconcelos et al., 1995; Warthmann et al., 2000) and by removing sulfate, a known inhibitor to dolomite formation (Baker and Kastner, 1981). SRB may be important in mediating dolomite precipitation in nature, such as modern saline lakes and lagoons (Vasconcelos and McKenzie, 1997; Wright, 1999; Wright and Oren, 2005). One halophilic SRB that can promote dolomite precipitation has recently been isolated from a hypersaline coastal lagoon, Lagoa Vermelha, Rio de Janeiro, Brazil (Warthmann et al., 2005). Some halophilic (salt-loving) bacteria can precipitate dolomite even in the presence of sulfate (Sanchez-Roman et al., 2005) and they may account for primary precipitation of dolomite in modern hypersaline environments. Methanogens may also be important in mediating dolomite precipitation (Roberts et al., 2004). These results collectively suggests that SRB, halophiles, and methanogens all play important role in dolomite formation, especially in saline environments.

Gas-hydrate and methane-seep deposits in deep oceans are the largest potential fossil fuel reservoirs on Earth, and they play an important role in regulating the global carbon cycle. Formation of dolomite in these environments is globally significant, both in modern (Baker and Burns, 1985; Kulm and Suess, 1990; Matsumoto, 1990; Roberts and Aharon, 1994; vonRad et al., 1996; Sample and Reid, 1998; Stakes et al., 1999; Aloisi et al., 2000; Rodriguez et al., 2000; Greinert et al., 2001; Formolo et al., 2004; Sassen et al., 2004) and ancient (Jorgensen, 1992; Terzi et al., 1994; Cavagna et al., 1999; Peckmann et al., 1999; Peckmann et al., 2001; Peckmann and Thiel, 2004; Pierre and Rouchy, 2004) methane seeps and gas hydrate deposits. Multiple studies have found negative $\delta^{13} \mathrm{C}$ values of authigenic dolomite associated with these deposits (Kulm and Suess, 1990; Matsumoto, 1990; Jorgensen, 1992; Roberts and Aharon, 1994; Sample and Reid, 1998; Peckmann et al., 1999; Stakes et al., 1999; Aloisi et al., 2000; Rodriguez et al., 2000; Greinert et al., 2001; Peckmann et al., 2001; Campbell et al., 2002; Pierre and Rouchy, 2004; Sassen et al., 2004), implying that dolomite may be formed by microbial oxidation of methane or organic matter coupled with sulfate reduction (Mazzullo, 2000). A recent study shows that dolomite formation in organic-rich marine sediments is controlled in part by competition between anaerobic methane oxidation and methanogenesis, which controls the speciation of dissolved $\mathrm{CO}_{2}$. AMO increases the concentration of $\mathrm{CO}_{3}{ }^{2-}$ through sulfate reduction, favoring dolomite formation, while methanogenesis increases the $\mathrm{pCO}_{2}$ of the pore waters, inhibiting dolomite formation (Moore et al., 2004). However, a direct link between a microbial function and dolomite 
formation pathways has not been established for important carbon reservoirs such as gas-hydrate and methane-seep deposits. Moreover, dolomite formation under the in-situ conditions of gas-hydrate deposits has not been demonstrated in the laboratory.

\section{Dry deserts}

Deserts are widely distributed on Earth and include both hot and cold environments (Antarctic). One common characteristic of these environments is the scarcity of water. As a result, water is the most important limiting condition in deserts. Photosynthetic cyanobacteria are the primary inhabitants in these environments (WynnWilliams, 2000). These primary producers typically live a few millimeters below the surface of translucent rocks, such as quartz (Schlesinger et al., 2003; Warren-Rhodes et al., 2006; WarrenRhodes et al., 2007), sandstone pebbles (Wynn-Williams, 2000); halite (Wierzchos et al., 2006), and gypsum (Dong et al., 2007) (Figure. 3). This micro-habitat is apparently achieved as a result of balance between a sufficient supply of $\mathrm{CO}_{2}, \mathrm{~N}_{2}$ and light to allow photosynthesis and $\mathrm{N}_{2}$ fixation on the one hand (Rothschild et al., 1994) and protection from intolerable levels of irradiation, high temperature, and arid surface condition (Cockell et al., 2005) on the other. Even $1 \mathrm{~mm}$ of rock matrix could provide a sufficient shielding effect of UV-radiation (Cockell et al., 2005) to allow photosynthesis to proceed. Douglas and Yang (2002) found different types of cyanobacteria colonizing gypsum, bassanite, and halite in distinct layers of color in an evaporite deposit from Death Valley, California, USA. From top down, the color changes from uncolonized, to orange-brown, to blue-green, and finally purple. This color change reflects different cyanobacterial community composition and may suggest that different phototrophic communities may have different demands of water moisture and tolerance of UV radiation. The effect of water availability is not only reflected in vertical succession but also in lateral distribution of phototrophic bacteria. In a recent study, Warren-Rhodes et al. (2007) measured the abundance and spatial distribution of cyanobacterial colonization on quartz stony pavements across environmental gradients of rainfall and temperature in the isolated Taklimakan and Qaidam Basin deserts of western China. The authors found that site-level differences in cyanobacterial spatial distribution pattern (e.g. mean inter-patch distance) were linked with rainfall, whereas patchiness within sites was correlated with local geology (greater colonization frequency of large rocks) and biology (dispersal during rainfall).

Heterotrophic bacteria also occur widely in desert environments and their abundance appears to be related to mean annual precipitation. In the hyperarid core region of the Atacama Desert, the heterotrophic community preferably inhabits the soil subsurface (25-30 cm in depth) (Drees et al., 2006), rather than the more hostile surface (Navarro-Gonzalez et al., 2003). A survey of multiple desert environments appears to indicate that the heterotrophic community composition is mainly composed of Alphaproteobacteria, Acti-

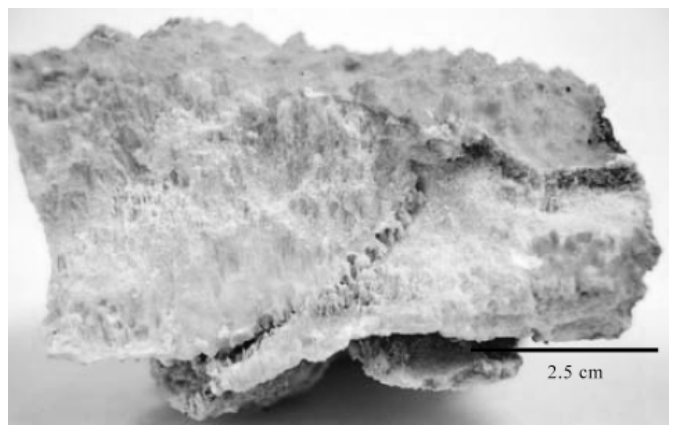

Figure 3 A green layer of colonized cyanobacteria in gypsic crust from the Atacama Desert. The colonization depth is optimized for photosynthesis. Adopted from Dong et al. (2007). nobacteria, Flexibacteria, Firmicutes, Gemmatimonadetes, Planctomycetes, and Thermus/Deinococcus (de la Torre et al., 2003; Navarro-Gonzalez et al., 2003; Nagy et al., 2005; Chanal et al., 2006; Drees et al., 2006). The metabolic functions of these groups in such environments remain largely speculative. Some members of Alphaproteobacteria may be potentially capable of aerobic anoxygenic photosynthesis (de la Torre et al., 2003).

Deserts have been proposed as a good analog for Mars, because these two environments share many common characteristics. Among these are presence of sulfate deposits (Cooper and Mustard, 2002; Hughes and Lawley, 2003; Squyres et al., 2004; Gendrin et al., 2005; Langevin et al., 2005; Aubrey et al., 2006), low levels of refractory organic material, low number of detectable bacteria, and equal oxidation of $\mathrm{L}$ and $\mathrm{D}$ amino acids (Wierzchos et al., 2006). Organic materials may be preserved for geologically long periods in sulfate minerals (Aubrey et al., 2006). Indeed, salt deposits (halite and possibly sulfate) are one of the four possible life habitats on Mars as predicted by a radiative transfer model (Cockell and Raven, 2004), and microbial life and their signatures in such deposits may be remotely detected by non-destructive spectroscopy methods, even when microbes colonize a few $\mathrm{mm}$ below the rock surface (Edwards et al., 2005a). Microorganisms from desert environments have typically been adapted to extreme desiccation (Billi et al., 2000) and radiation (Rainey et al., 2005), prevalent conditions on Mars and possibly other planets. When these organisms colonize the subsurface of rocks, their ability to resist radiation and desiccation is significantly enhanced (Cockell et al., 2005), apparently due to the shielding effect of rock matrix.

\section{Fossil DNA and the concept of Paleome}

Recent developments in molecular microbiology in the last decade have allowed us to investigate the abundance, distribution, and identity of microorganisms in various extreme environments independent of cultivation (Giovannoni et al., 1990; DeLong, 1992; Barns et al., 1996; Pace, 1997; Hugenholtz et al., 1998; Takai and Horikoshi, 1999). These new techniques have been used to not only study microorganisms in modern environments, but also in ancient rocks, i.e., fossil DNA. A few pilot studies have shown a great promise in reconstructing paleomicrobial communities and paleoenvironmental conditions through investigations of fossil DNA and biomarkers preserved in sediments and sedimentary rocks (Coolen and Overmann, 1998; Coolen et al., 2004; Coolen and Overmann, 2007). Inagaki et al. (2001) studied the microbial community of an oceanic sub-seafloor core sample of the Pleistocene age $(1410 \mathrm{~cm}$ long, $\sim 2-2.5 \mathrm{Ma}$ ) recovered from the West Philippine Basin at a depth of $5719 \mathrm{~m}$. The authors reported the discovery of vertically shifted community structures of archaea. Beneath a surface community of ubiquitous deep-sea archaea, an unusual archaeal community consisting of extremophilic archaea, such as extreme halophiles and hyperthermophiles, was present. These organisms were interpreted to be microbial relicts, more than 2 million years old. The discovery of an unusual archaeal community in this core sample, inconsistent with the deep-sea environment, was inferred to reflect past terrestrial volcanic and submarine hydrothermal activities surrounding the West Philippine Basin.

In 2005, Inagaki et al. proposed the concept of "Paleome" for the first time: "the use of preserved DNA and/or microbes to interpret the past". The authors successfully extracted and amplified DNA from a core sample of black shale of the Cretaceous age (100 Ma) collected from Serre des Castets, near Marseilles, France. The authors eliminated the possibility of contamination possibly caused during the drilling and the sample processing. The DNA sequences were most similar to those commonly found in deep-sea sedimentary environments, which prevailed during the deposition of black shales, but different from those commonly found in the modern terrestrial environment of the drill core. Moreover, the inferred aerobic/anaerobic habitats, based on relatedness of the detected DNA sequences to cul- 
tivated microorganisms, were consistent with the inferred paleoenvironmental conditions. In particular, a number of $16 \mathrm{~S}$ rRNA gene clones of oceanic sulfate-reducing bacteria within the Deltaproteobacteria predominated at the oceanic anoxic event (OAE) layer of the Cretaceous black shale, but the number of clones of sulfatereducing bacteria dramatically diminished in the sediment layers above and below the OAE layer. Instead, extant deep-sea genera predominated in these layers, including some psychrophilic and piezophilic members. Based on this correlation, the authors proposed the idea of "fossil DNA". The detected DNA sequences were inferred to represent the relics of fossil microbial communities, not the modern microorganisms living within the black shale.

If proved to be genuine, this discovery has significant implications for the following three reasons:

1. Fossil DNA in black shales can be used to understand microbial community structure, growth habitats, and their roles in global elemental cycling during the Cretaceous.

2. Because of global distribution of black shales and the abundant information that they contain, fossil DNA within these rocks can be used to reconstruct global environments during the Cretaceous.

3. Fossil DNA provides an effective means to study biological evolution. Evolution of various processes throughout geological time, such as elemental cycling, chemical composition of the oceans, the atmosphere, and the crust, diversification of metabolism, and origins of multicellular organisms, is all intimately correlated with microbial evolution.

Despite the fact that the concept "Paleome" is supported by strong evidence, it is faced with many challenges and issues. The most important issue to be addressed is whether or not DNA can be preserved for such a long time ( 100 Ma). Although previous studies have shown that dormant bacteria and archaea have been detected or cultivated within fluid inclusions of ancient halite crystals as old as $250 \mathrm{Ma}$ (Vreeland et al., 2000; Fish et al., 2002; Kminek et al., 2003), Inagaki et al. (2005) were the first to detect DNA in ancient, low-salinity black shales. In natural environments, aqueous solution, oxidizing environment, and radiation can all damage isolated DNA (outside living microbes) (Lindahl, 1993; Kminek et al., 2003). Laboratory experiments have shown that under conditions of water availability and moderate temperature, DNA can not be preserved for more than a few thousand years (Lindahl, 1993). Similar to this result, in lake sediments of up to 11,000 years, the DNA abundance of phototrophic microorganisms decreases by six orders of magnitude (Coolen and Overmann, 1998). However, DNA preservation is favorable under low-temperature and high-salinity conditions, especially under conditions of dry, anoxic, and clay-rich environments. Recent studies have shown that clay minerals can stabilize adsorbed DNA molecules (Ciaravella et al., 2004; Scappini et al., 2004). Inagaki et al. (2005) believe that the relatively dry, anoxic and clay-rich environments within their black shale are favorable factors for preserving ancient DNA molecules for as long as $100 \mathrm{Ma}$ (Cretaceous).

In addition to the issue of DNA preservation, many other issues remain: 1) Does the age of the black shale represent the detected microorganisms? 2) When did the microorganisms enter the black shale to become isolated from the outside world? 3) When did the detected microorganisms stop metabolic activity and become fossils? Available evidence suggests that metabolic activity can exist long after sedimentation, ranging from hundreds of thousands of years to millions of years (Parkes et al., 1994; D'Hondt et al., 2004). Thus, ancient rocks may not necessarily contain ancient DNA. If not all microorganisms stopped metabolic activity and became preserved when the rock formed, but a small fraction of the population remained active, then the preserved (and detected) DNA does not represent the microbial community at the time of rock formation, and cannot be used to infer the paleoenvironmental conditions. These issues are important for the study of microbial evolution in a geological context, but they were not addressed in that particular study (Inagaki et al., 2005). Lack of archaeal DNA in the black shale (Inagaki et al., 2005) is another important issue to be resolved, because in general, archaea should be abundant in marine environ- ments (Kuypers et al., 2001; Kuypers et al., 2002; Sinninghe Damsté and Coolen, 2006).

In 2006, Sinninghe and Coolen (2006) published a comment paper and pointed out a few weaknesses in the original Inagaki et al. paper (2005). The main criticisms are reflected in three aspects:

1. The Inagaki et al. (2005) study lacks biomarker work. Lipid biomarkers can be specific to microbial functional groups, and these compounds can be preserved in rocks longer than DNA molecules. A few studies (Kuypers et al., 2001; Kuypers et al., 2002; Tsikos et al., 2004) have detected archaeal lipid biomarkers in similar black shales to those studied by Inagaki et al. (2005), which is inconsistent with the lack of fossil archaeal DNA as reported by Inagaki et al. (2005). This inconsistency raises the possibility of DNA contamination in the Inagaki et al. study (Sinninghe Damsté and Coolen, 2006). However, archaeal DNA may be degraded more easily than bacterial DNA (Inagaki and Nealson, 2006), as evidenced in modern sediments (MacGregor et al., 1997; MacGregor et al., 2001). Thus, this issue remains to be resolved.

2. Sinninghe Damste and Coolen (2006) believe that the molecular clock rate of the rRNA gene in diatoms is $1 \%$ per 14 million years (Damste et al., 2004). With this molecular clock rate, it is expected that fossil DNA sequences of 112 million years should be $8 \%$ different from those of modern organisms. The DNA sequences detected by Inagaki et al. (2005) are closely related to those of modern organisms. However, the molecular clock rate is not well determined and this inference may not be quantitative.

3. If the sulfate-reducing bacteria are related to methane emissions in deep-sea cold seeps, then the $\delta^{13} \mathrm{C}$ of lipid compounds should be very negative, because the lipid compounds should have been derived from biogenic methane $\left(\delta^{13} \mathrm{C}=-80 \%\right)$ (Sinninghe Damsté and Coolen, 2006). However, Inagaki et al. (2005) did not measure carbon isotopes of lipid compounds.

The debate over the concept "Paleome" will likely continue in the foreseeable future. The only way to validate this concept is through further testing. Fortunately, more opportunities have become available for such tests. For example, the Songliao Basin in Northeastern China hosts a terrestrial record of Cretaceous black shales as thick as 5,000 m (Chen, 1987; Chen and Chang, 1994). One unique feature in this location is the alternation of black and red beds, presumably reflecting alternating reducing and oxidizing conditions during the Cretaceous (Wang et al., 2005). These rock formations have not been heated to more than $100^{\circ} \mathrm{C}$, and they are ideal for microbiological work. Furthermore, abundant information on the paleoclimate, paleogeography, and paleoenvironment is available, based on which microbial data can be interpreted.

\section{Ocean research}

Oceans cover more than two-thirds of the Earth's surface and they are full of life. Geomicrobiological processes in the global oceans have received increased interest in the last decade, as exemplified by many excellent research papers and books (Wilcock et al., 2004; Edwards et al., 2005b; Teske, 2006). Considering the rapid pace of the recent developments in this area, it is nearly impossible to write a comprehensive review. Below we lightly touch on five aspects: biomass abundance, diversity, some important metabolic functions, carbon sources, and microbial effects on geological processes. We discuss these aspects in three representative environments of oceans: "normal" deep-sea sediments, gas hydrate deposits, and hydrothermal vents.

\section{Biomass abundance and distribution.}

Microbial biomass generally decreases with increasing depth in deep-sea sediments, from $1.4-4 \times 10^{9} / \mathrm{cm}^{3}$ at the surface sediment to $2.76 \times 10^{6} / \mathrm{cm}^{3}$ at the average ocean sediment depth $(500 \mathrm{~m})$ (Parkes et al., 2000). Prokaryotic populations have been detected in sediments as deep as 800 meters below the seafloor (mbsf) by both intact 
cells and intact membrane lipids. The total prokaryotic biomass in marine subsurface has been estimated to be $50-80 \%$ of Earth's total prokaryotic biomass $\left(4-6 \times 10^{30}\right.$ cells) (Whitman et al., 1998). The living prokaryotic biomass is estimated at $1.3 \times 10^{29}$ cells, at about $10 \%$ of the total prokaryotic biomass (Schippers et al., 2005). Bacterial populations and activity can increase near geochemical hotspots in deeper sediment layers, such as brine incursion or the presence of thermogenic methane (Parkes et al., 2000). Temperature, age and porosity appear to be three factors responsible for decreased biomass with sediment depth. Ancient sediments contain less biodegradable organic matter and are less likely to support microbial growth. One exception is gas hydrate deposits in deep sediments, where low molecular weight and fatty acids are produced by thermogenic and biogenic processes. In such settings, high biomass is likely to exist.

\section{Microbial diversity}

The known diversity on Earth includes approximately 6,000 species of prokaryotes (http://www.bacterio.cict.fr/number.html), based on cultivated species (Pedros-Alio, 2006). The unknown diversity is currently being explored by using molecular microbiology techniques. Estimated bacterial diversity in the sea was a few thousand taxa (Hagstrom et al., 2002), but more recently, approximately 360 new bacterial taxa per year are being submitted to GenBank, reaching a total diversity of 1,000 to 10,000 taxa (Pommier et al., 2005). Because of the insufficient nature of clone-library-based estimates of microbial diversity, the actual diversity is probably much larger, probably on the order of $10^{6}$ to $10^{9}$ bacterial taxa.

Microbial communities of deep marine sediments harbor members of distinct, uncultured archaeal and bacterial lineages (Teske, 2006). There are nine groups of the Archaea, as reviewed by Teske (2006). Among these, the Marine Benthic Group B Archaea (MBGB) show a cosmopolitan occurrence pattern in a wide spectrum of marine sediments, surficial as well as subsurface, and normal marine sediments as well as hydrothermal vents. The second major group is Marine Group I, which is abundant in both water column and subsurface sediments. Recent evidence shows that this group may be facultatively autotrophic or show broad metabolic diversity. An autotrophic aerobic ammonia oxidizer belongs to this group (Konneke et al., 2005). Unlike MBG-B and MGI, Archaea of the Marine Benthic Groups A and D are not abundant in deep-sea sediments. A few other groups occur in both marine and terrestrial subsurfaces, such as the MCG (Miscellaneous Crenarchaeotal Group), the SAGMEG (South African Goldmine Euryarchaeotal Group), and the TMEG (Terrestrial Miscellaneous Euryarchaeotal Group). Inagaki et al. (2006) reported the dominance of a deep-sea archaeal group (DSAG) in gas hydrate-bearing sediments, which appears to be absent in the gas hydrate-free sediments. The Proteobacteria, the candidate division JS-1 (Webster et al., 2004), and the Chloroflexi division are three groups of the domain Bacteria identified in normal marine sediments by molecular methods. Cultivation yields a somewhat different picture: the Firmicutes (specifically Bacillus and Thermosediminibacter) and the Actinobacteria, a range of Alphaproteobacteria (Rhizobium radiobacter) and Gammaproteobacteria (genera Photobacterium, Vibrio, Shewanella, and Halomonas), and a novel member of the Bacteroidetes phylum are commonly recovered (Teske, 2006).

In contrast to normal marine sediments, thermophilic and hyperthermophilic archaea and bacteria dominate deep-sea hydrothermal environments (Miroshnichenko and Bonch-Osmolovskaya, 2006). Archaea are represented by thermophilic, lithotrophic methanogens (Methanococcales and Methanopyrales); hyperthermophilic sulfate- and thiosulfate-reducing Archaeoglobales; hyperthermophilic, lithoautotrophic Pyrolobus fumarii; and thermophilic, organotrophic Thermococcales, Pyrodictium, and Staphylothermus. Recently, a few novel isolates have been obtained, including hyperthermophilic, lithotrophic, sulfur-respiring Ignicoccus pacificus of the family Desulfurococcaceae of the Crenarchaeota kingdom; hyperthermophilic, ferric iron reducing Geoglobus ahangari and Geogemma barossii; hyperthermophilic methanogens of the genera
Methanothermococcus, Methanocaldococcus, and Methanotorris; and hyperthermophilic organotrophic species within the order Thermococcales. Molecular surveys and cultivations have revealed the following bacterial diversity: the order Aquificales; the subclass Epsilonproteobacteria; the order Thermotogales; the families Thermodesulfobacteriaceae, Deferribacteraceae, and Thermaceae; the family Geobacteraceae; Firmicutes; and a novel phylum represented by the genus Caldithrix. Most isolates within these orders and families are obligate or facultative lithotrophs, oxidizing molecular hydrogen in the course of different types of anaerobic respiration or microaerobic growth (Miroshnichenko and Bonch-Osmolovskaya, 2006).

\section{Metabolic functions}

Large sulfate and methane gradients are typically observed in marine subsurface sediments (D'Hondt et al., 2002; 2004) and are usually assumed to have been caused by vertically stratified sulfate reducers and methanogens. Sulfate-reducers are expected to dominate in the sulfate-containing upper sediment layers; methanogenic Archaea are expected in the methane-rich deeper sediment layers; and sulfate-dependent, methanotrophic consortia analogous to those found at gas hydrate deposits and hydrothermal sediments (Hinrichs et al., 1999; Boetius et al., 2000; Orphan et al., 2001; Hinrichs and Boetius, 2002; Michaelis et al., 2002; Teske et al., 2002; Teske et al., 2003) are expected to dominate the sulfate-methane transition zone. However, functional gene surveys do not detect abundant dissimilatory sulfate reductase $(\mathrm{dsr} A \mathrm{~B})$ and methyl-coenzyme $\mathrm{M}$ reductase (mcrA). One possible explanation is that sulfate reducers and methanogens may be minor components in the overall community. Low rates of methanogenesis and sulfate reduction may be sufficient to maintain the observed sulfate and methane profiles (D'Hondt et al., 2004), or some uncultivated prokaryotes may be sulfate-reducers and methanogens (Teske, 2006).

Knowledge of metabolic functions in hydrothermal sediments is limited, largely because of the difficulty of obtaining isolates in this environment. Among the Archaea, three main functions have been identified: reduction of elemental sulfur with oxidation of $\mathrm{H}_{2}$ (by Ignicoccus pacificus), iron reduction, and methanogenesis (Miroshnichenko and Bonch-Osmolovskaya, 2006). Among the Bacteria, identified metabolic functions include organotrophy (thermophilic and piezophilic representatives within the order Thermotogales, representatives within the family Thermaceae and Firmicutes) (Reysenbach, 2001a); lithoautotrophy [i.e., Aquificales using $\mathrm{H}_{2}, \mathrm{~S}^{0}$, $\mathrm{S}_{2}^{-}$or $\mathrm{S}_{2} \mathrm{O}_{3}{ }^{2-}$ as energy sources and $\mathrm{O}_{2}, \mathrm{NO}_{3}{ }^{-}$, or $\mathrm{S}^{0}$ as electron acceptors (Reysenbach, 2001b); representatives of the subgroup A of the Epsilonproteobacteria]; sulfate-reduction (representatives within the Thermodesulfobacteriaceae family); iron reduction (within the order Deferribacterales and the family Geobacteraceae within the subclass Deltaproteobacteria); and $\mathrm{H}_{2}$ oxidation coupled with reduction of elemental sulfur and nitrate (representatives of the Epsilonproteobacteria).

In gas hydrate deposits, the main metabolic functions are sulfate reduction coupled with oxidation of methane and/or hydrocarbons (Valentine and Reeburgh, 2000; Orphan et al., 2001; Thomsen et al., 2001; Nauhaus et al., 2002; Teske et al., 2003; Orcutt et al., 2004). Methane is either microbial or abiotic in origin, and it migrates upward from deep sediments, where it meets sulfate that diffuses downward from seawater. When methane and sulfate meets at the transition, steep gradients of methane and sulfate develop, where sulfate-reducing bacteria and methane oxidizing archaea work together to form a coupled reaction (Valentine and Reeburgh, 2000). A few studies have shown that the rate of sulfate reduction generally exceeds the rate of anaerobic oxidation of methane and the two processes are loosely coupled, suggesting that the majority of sulfate reduction is likely fueled by the oxidation of other organic matter (Formolo et al., 2004; Joye et al., 2004). Increased alkalinity from oxidation of methane and other organic matter results in formation of authigenic carbonates (Moore et al., 2004; Sassen et al., 2004). 


\section{Carbon sources fuelling marine subsurface microorganisms}

On the Earth's surface (both terrestrial and ocean surfaces), within the water column, and in marine sediments, essentially all life forms rely either directly or indirectly on the energy supplied by the sun and incorporated into biomass by photosynthetic organisms. In the marine subsurface, microorganisms essentially depend on "dark energy", reduced chemical species (including $\mathrm{H}_{2}$ ) derived from the oceanic crust, as a main energy source. Using chemical energy, lithioautotrophic organisms are alive and well (Teske, 2005). Using catalysed reporter deposition-fluorescence in-situ hybridization (CARD-FISH), Schippers et al. (2005) identified that a fraction of the sub-seafloor prokaryotes $(\sim 4 \%)$ is alive, even in very old (10 million yr) and deep (>400 m) sediments. All detectable living cells belong to the Bacteria and have turnover times of 0.25-22 yr, comparable to surface sediments. This raises a question of energy source in the deep subsurface. Unlike organic-rich continental shelf sediments and gas hydrate deposits, carbon sources in deep-sea sediments are usually limited. For lithoautotrophic organisms, carbon sources are abundant, in the form of $\mathrm{CO}, \mathrm{CO}_{2}$, and $\mathrm{CH}_{4}$. For heterotrophic organisms, organic matter is scarce in deep-sea sediments and it is not clear what possible organic carbon substrate there is. While it is known that fluids from 3.5-Ma oceanic crust are capable of supporting microbial growth (Cowen et al., 2003), including nitrate reducers, thermophilic sulfate reducers and thermophilic fermentative heterotrophs, whether or not abiotically produced carbon substrates can be used by microbes was not demonstrated until recently. Horsfield et al. (2006) demonstrated that abiotically driven degradation products of buried marine sedimentary organic matter can provide substrates for microbial activity in deep sediments at convergent continental margins and possibly in other deep-sea sedimentary environments as well. This study is highly significant in showing that refractory organic matter can be an important source of carbon for marine subsurface microorganisms.

\section{Microbial impacts on geological processes}

Microorganisms at and beneath the ocean floor play an important role in rock/glass alteration (Fisk et al., 1998; Furnes and Staudigel, 1999; Staudigel et al., 2006), chemical and isotopic exchange between the oceanic crust and the sea water (Furnes et al., 2001), and biogeochemical cycles of $\mathrm{C}, \mathrm{Fe}, \mathrm{S}$ and other elements (Fisk et al., 1998; Edwards et al., 2005b). The prominent role in subseafloor basalt weathering has been demonstrated in both laboratory culture study (Edwards et al., 2003b) and in-situ incubation experiments (Edwards et al., 2003a). In these studies, Fe- and Mn-oxidizing lithoautotrophs obtained from deep-sea environments have been demonstrated to be capable of growth on basalt glass as the sole source of energy, and they are found to enhance the rate of basalt dissolution by up to an order of magnitude (Edwards et al., 2004; Templeton et al., 2005). In these processes, they derive energy from oxidation of sulfides, methane, ferrous iron and manganese, and $\mathrm{H}_{2}$, reduction of ferric iron, sulfate, and $\mathrm{CO}_{2}$, and respiration and fermentation of organic matter.

Some unique textures result when microorganisms weather oceanic glass/basaltic glass, such as tubular structures (Thorseth et al., 1995; Fisk et al., 1998). These textures are typically accompanied by characteristic enrichments of certain elements and depletion of others, as well as isotopes (Thorseth et al., 1995; Furnes et al., 2001; Banerjee et al., 2006). Together, these features have been used as biosignatures to determine biogenicity of ancient rock records on the early Earth and on Mars. However, caution must be exercised in interpretation of the importance of this textural and geochemical evidence, unless other supporting evidence, such as lipid biomarkers, is presented.

\section{Acknowledgments}

This work was supported by the 111 Project (No. B07011) of China. Dong's former and current $\mathrm{PhD}$ students, Gengxin Zhang and Hongchen Jiang provided Figures 1 and 2.

\section{References}

Abrajano, T.A., Sturchio, N.C., Kennedy, B.M., Lyon, G.L., Muehlenbachs, K., and Bohlke, J.K., 1990, Geochemistry of reduced gas related to serpentinization of the Zambales ophiolite, Philippines: Applied Geochemistry, v.5, pp. 625-630.

Acinas, S.G., Sarma-Rupavtarm, R., Klepac-Ceraj, V., and Polz, M.F., 2005, PCR-induced sequence artifacts and bias: Insights from comparison of two 16S rRNA clone libraries constructed from the same sample: Applied and Environmental Microbiology, v.71, pp. 8966-8969.

Aloisi, G., Pierre, C., Rouchy, J.M., Foucher, J.P., Woodside, J., and Party, M.S., 2000, Methane-related authigenic carbonates of eastern Mediterranean Sea mud volcanoes and their possible relation to gas hydrate destabilisation: Earth and Planetary Science Letters, v.184, pp. 321-338.

Alt, J.C., and Shanks, W.C.I., 1998, Sulfur in serpentinized oceanic peridotites:Serpentinization processes and microbial sulfate reduction: Journal of Geophysical Research, v.103, pp. 9917-9929.

Amend, J.P., and Teske, A., 2005, Expanding frontiers in deep subsurface microbiology: Palaeogeography, Palaeoclimatology, Palaeoecology, v.219, pp. 131-155.

Aragno, M., 1992, Aerobic, chemolithoautotrophic, thermophilic bacteria. In Thermophilic bacteria. Kristjansson, J.K. (ed). Boca Raton: CRC Press, pp. 77-103.

Aubrey, A., Cleaves, H.J., Chalmers, J.H., Skelley, A.M., Mathies, R.A., Grunthaner, F.J. et al., 2006, Sulfate minerals and organic compounds on Mars: Geology, v.34, pp. 357-360.

Baker, P.A., and Kastner, M., 1981, Constraints on the formation of sedimentary dolomite: Science, v.213, pp. 214-216.

Baker, P.A., and Burns, S.J., 1985, The occurrence and formation of dolomite in organic-rich continental margin sediments: AAPG Bulletin, v.69, pp. 1917-1930.

Banciu, H., Sorokin, D.Y., Rijpstra, W.I.C., Damste, J.S.S., Galinski, E.A., Takalchi, S. et al., 2005, Fatty acid, compatible solute and pigment composition of obligately chemolithoautotrophic alkaliphilic sulfur-oxidizing bacteria from soda lakes: FEMS Microbiology Letters, v.243, pp. 181-187.

Banerjee, N.R., Furnes, H., Muehlenbachs, K., Staudigel, H., and de Wit, M., 2006, Preservation of similar to 3.4-3.5 Ga microbial biomarkers in pillow lavas and hyaloclastites from the Barberton Greenstone Belt, South Africa: Earth and Planetary Science Letters, v.241, pp. 707-722.

Barns, S.M., Delwiche, C.F., Palmer, J.D., and Pace, N.R., 1996, Perspectives on archaeal diversity, thermophily, and monophyly from environmental rDNA sequences: Proceedings of National Academy of Science of the USA, v.17, pp. 9188-9193.

Belyakova, E.V., Rozanova, E.P., Borzenkov, I.A., Tourova, T.P., Pusheva, M.A., Lysenko, A.M., and Kolganova, T.V., 2006, The new facultatively chemolithoautotrophic, moderately halophilic, sulfate-reducing bacterium Desulfovermiculus halophilus gen. nov., sp nov., isolated from an oil field: Microbiology, v.75, pp. 161-171.

Benlloch, S., Lopez-Lopez, A., Casamayor, E.O., Ovreas, L., Goddard, V. Daae, F.L. et al., 2002, Prokaryotic genetic diversity throughout the salinity gradient of a coastal solar saltern: Environmental Microbiology, v.4, pp. $349-360$

Berndt, M.E., Allen, D.E., and Seyfried, W.E., 1996, Reduction of $\mathrm{CO}_{2}$ during serpentinization of olivine at $300^{\circ} \mathrm{C}$ and 500 bar: Geology, v.24, pp. $351-354$

Bernhard, A.E., Colbert, D., McManus, J., and Field, K.G., 2005, Microbial community dynamics based on 16S rRNA gene profiles in a Pacific Northwest estuary and its tributaries: FEMS Microbiology Ecology, v.52, pp. 115-128.

Billi, D., Friedmann, E.I., Hofer, K.G., Caiola, M.G., and Ocampo-Friedmann, R., 2000, Ionizing-radiation resistance in the desiccation-tolerant cyanobacterium Chroococcidiopsis: Applied and Environmental Microbiology, v.66, pp. 1489-1492.

Bockelmann, U., Manz, W., Neu, T.R., and Szewzyk, U., 2000, Characterization of the mcirobial community of lotic organic aggregates ('river snow') in the Elbe River of Germany by cultivation and molecular methods: FEMS Microbiology Ecology, v.33, pp. 157-170. 
Boetius, A., Ravenschlag, K., Schubert, C.J., Rickert, D., Widdel, F., Gieseke, A. et al., 2000, A marine microbial consortium apparently mediating anaerobic oxidation of methane: Nature, v.407, pp. 623-626.

Bouvier, T.C., and del Giorgio, P.A., 2002, Compositional changes in freeliving bacterial communities along a salinity gradient in two temperate estuaries: Limnology and oceanography, v.47, pp. 453-470.

Brambilla, E., Hippe, H., Hagelstein, A., Tindall, B.J., and Stackbrandt, E., 2001,16 S diversity of cultured and uncultured prokaryotes of a mat sample from Lake Fryxell, McMurdo Dry Valleys: Antarctica. Extremephiles, v.5, pp. 23-33.

Bridge, T.A.M., and Johnson, D.B., 1998, Reduction of soluble iron and reductive dissolution of ferric iron-containing minerals by moderately thermophilic iron-oxidizing bacteria: Applied and Environmental Microbiology, v.64, pp. 2181-2186.

Brummer, I.H., Felske, A.D., and Wagner-Dobler, I., 2004, Diversity and seasonal changes of uncultured planctomycetales in river biofilms: Applied and Environmental Microbiology, v.70, pp. 5094-5101.

Cai, C.F., Dong, H., Li, H., Xiao, X., and Ou, G., 2007, Mineralogical and geochemical evidence for coupled bacterial uranium mineralization and hydrocarbon oxidation in the Shashagetai deposit, NW China: Chemical Geology, v.236, pp. 167-179.

Campbell, K.A., Farmer, J.D., and Des Marais, D., 2002, Ancient hydrocarbon seeps from the Mesozoic convergent margin of California: carbonate geochemistry, fluids and palaeoenvironments: Geofluids, v.2, pp. 63-94.

Cavagna, S., Clari, P., and Martire, L., 1999, The role of bacteria in the formation of cold seep carbonates: geological evidnece from Monferrato (Tertiary, NW Italy):. Sedimentary Geology, v.126, pp. 253-270.

Chanal, A., Chapon, V., Benzerara, K., Barakat, M., Christen, R., Achouak, W. et al., 2006, The desert of Tataouine: an extreme environment that hosts a wide diversity of microorganisms and radiotolerant bacteria: Environmental Microbiology, v.8, pp. 514-525.

Chapelle, F.H. (2000) Ground-Water Microbiology and Geochemistry: New York: John Wiley \& Sons, Inc.

Chapelle, F.H., O'Neill, K., Bradley, P.M., Methe, B.A., Ciufo, S.A., Knobel, L.L., and Lovley, D.R., 2002, A hydrogen-based subsurface microbial community dominated by methanogens: Nature, v.415, pp. 312-315.

Charlou, J.L., and Donval, J.P., 1993, Hydrothermal methane venting between $12 \mathrm{oN}$ and $26 \mathrm{oN}$ along the Mid-Atlantic Ridge: Journal of Geophysical Research, v.98, pp. 9625-9642.

Charlou, J.L., Donval, J.P., Fouquet, Y., Jean-Baptiste, P., and Holm, N., 2002, Geochemistry of high $\mathrm{H}_{2}$ and $\mathrm{CH}_{4}$ vent fluids issuing from ultramafic rocks at the Rainbow hydrothermal field (36o 14'N, MAR): Chemical Geology, v.191, pp. 345-359.

Charlou, J.L., Fouquet, Y., Bougault, H., Donval, J.P., Etoubleau, J., JeanBaptiste, P. et al., 1998, Intense $\mathrm{CH}_{4}$ plumes generated by serpentinization of ultramafic rocks at the intersection of the $15^{\circ} 20^{\prime} \mathrm{N}$ fracture zone and the Mid-Atlantic Ridge: Geochimica et Cosmochimica Acta, v.62, pp. 2323-2333.

Chen, P.J., 1987, Cretaceous paleogeography of China: Palaeogeography, Palaeoclimatology, Palaeoecology, v.59, pp. 49-56.

Chen, P.J., and Chang, Z.L., 1994, Nonmarine Cretaceous stratigraphy of eastern China: Cretaceous Research, v.5, pp. 245-257.

Ciaravella, A., Scappini, F., Franchi, M., Cecchi-Pestellini, C., Barbera, M., Candia, R. et al., 2004, Role of clays in protecting adsorbed DNA against X-ray radiation: International Journal of Astrobiology, v.3, pp. 31-35.

Cockell, C.S., and Raven, J.A., 2004, Zones of photosynthetic potential on Mars and the early Earth: ICARUS, v.169, pp. 300-310.

Cockell, C.S., Schuerger, A.C., Billi, D., Friedmann, E.I., and Panitz, C., 2005, Effects of a simulated martian UV flux on the cyanobacterium, Chroococcidiopsis sp 029: Astrobiology, v.5, pp. 127-140.

Coolen, M.J.K., Hopmans, E.C., Rijpstra, W.I.C., Muyzer, G., Schouten, S., Volkman, J.K., and Sinninghe-Damste, J.S., 2004, Evolution of the methane cycle in Ace Lake (Antarctica) during the Holocene: response of methanogens and methanotrophs to environmental change: Organic Geochemistry, v.35, pp. 1151-1167.

Coolen, M.J.L., and Overmann, J., 1998, Analysis of subfossil molecular remains of purple sulfur bacteria in a lake sediment: Applied and Environmental Microbiology, v.64, pp. 4513-4521.

Coolen, M.J.L., and Overmann, J., 2007, 217 000-year-old DNA sequences of green sulfur bacteria in Mediterranean sapropels and their implications for the reconstruction of the paleoenvironment: Environmental Microbiology, v.9, pp. 238-249.

Cooper, C.D., and Mustard, J.F., 2002, Spectroscopy of loose and cemented sulphate-bearing soils: implications for duricrust on Mars: ICARUS, v.158, pp. 42-55.

Cottrell, M.T., and Kirchman, D.L., 2003, Contribution of major bacterial groups to bacterial biomass production (thymidine and leucine incorpora- tion) in the Delaware estuary: Limnology and Oceanography, v.48, pp. $168-178$.

Cowen, J.P., Giovannoni, S.J., Kenig, F., Johnson, H.P., Butterfield, D., Rappe, M.S. et al., 2003, Fluids from aging ocean crust that support microbial life: Science, v.299, pp. 120-123.

Crump, B.C., Armbrust, E.V., and Baross, J.A., 1999, Phylogenetic analysis of particle-attached and free-living bacterial communities in the Columbia river, its estuary, and the adjacent coastal ocean: Appl Environ Microbiol 65: 3192-3204.

Cytryn, E., Minz, D., Oremland, R.S., and Cohen, Y., 2000, Distribution and diversity of archaea corresponding to the limnological cycle of a hypersaline stratified lake (Solar Lake, Sinai, Egypt): Applied and Environmental Microbiology, v.66, pp. 3269-3276.

D'Hondt, S., Rutherford, S., and Spivack, A.J., 2002, Metabolic activity of subsurface life in deep-sea sediments. Science, v.295, pp. 2067-2070.

D'Hondt, S., Jørgensen, B.B., Miller, D.J., Batzke, A., Blake, R., Cragg, B.A. et al., 2004: Distributions of Microbial Activities in Deep Subseafloor sediments. Science, v.306, pp. 2216-2221.

Damste, J.S.S., Muyzer, G., Abbas, B., Rampen, S.W., Masse, G., Allard, W.G. et al., 2004, The rise of the rhizosolenid diatoms: Science, v.304, pp. 584-587.

DasSarma, S., and Arora, P. (2001) Halophiles. In Encyclopedia of life Sciences: Macmillan Press, pp. 1-9.

de la Torre, J.R., Goebel, B.M., Friedmann, E.I., and Pace, N.R., 2003, Microbial diversity of cryptoendolithic communities from the McMurdo Dry Valleys, Antarctica: Applied and Environmental Microbiology, v.69, pp. 3858-3867.

DeFlaun, M.F., Fredrickson, J.K., Dong, H., Pfiffner, S.M., Onstott, T.C., Balkwill, D.L. et al., 2007, Isolation and characterization of a Geobacillus thermoleovorans strain from an ultra-deep South African gold mine: Systematic and Applied Microbiology, v.30, pp. 152-164.

del Giorgio, P.A., and Bouvier, T.C., 2002, Linking the physiologic and phylogenetic successions in free-living bacterial communities along an estuarine salinity gradient: Limnology and Oceanography, v.47, pp. 471-486.

DeLong, E.F., 1992, Archaea in coastal marine environments: Proceedings of National Academy of Science, v.89, pp. 5685-5689.

DeLong, E.F., Franks, D.G., and Alldredge, A.L., 1993, Phylogenetic diversity of aggregate-attached vs. free-living marine bacterial assemblages: Limnology and Oceanography, v. 38: 924-934.

Demergasso, C., Casamayor, E.O., Chong, G., Galleguillos, P., Escudero, L., and Pedros-Alio, C., 2004, Distribution of prokaryotic genetic diversity in athalassohaline lakes of the Atacama Desert, Northern Chile: FEMS Microbiology Ecology, v.48, pp. 57-69.

Dong, H., Rech, J.A., Jiang, H., Sun, H., and Buck, B.J., 2007, Endolithic cyanobacteria in soil gypsum: Occurrences in Atacama (Chile), Mojave (United States), and Al-Jafr Basin (Jordan) deserts. Journal of Geophysical Research-Biogeosciences, v.112, pp. doi:10.1029/2006JG000385.

Douglas, S., and Yang, H.X., 2002, Mineral biosignatures in evaporites: presence of rosickyite in an endoevaporitic microbial community from Death Valley, California. Geology, v.30, pp. 1075-1078.

Drees, K.P., Neilson, J.W., Betancourt, J.L., Quade, J., Henderson, D.A., Pryor, B.M., and Maier, R.M., 2006, Bacterial diversity in the hyper-arid core of the Atacama desert, Chile: Applied and Environmental Microbiology, 72(12), 7902-7908.

Edwards, H.G.M., Villar, S.E.J., Parnell, J., Cockell, C.S., and Lee, P., 2005a, Raman spectroscopic analysis of cyanobacterial gypsum halotrophs and relevance for sulfate deposits on Mars. Analyst, v.130, pp. 917-923.

Edwards, K., Bach, W., McCollom, T., and Rogers, D., 2004, Neutrophilic Iron-Oxidizing Bacteria in the Ocean: Their Habitats, Diversity, and Roles in Mineral Deposition, Rock Alteration, and Biomass Production in the Deep-Sea Geomicrobiology Journal, v.21, pp. 393-404.

Edwards, K.J., Bach, W., and McCollom, T.M., 2005b, Geomicrobiology in oceanography: microbe-mineral interactions at and below the seafloor Trends in Microbiology, v.13, pp. 449-456.

Edwards, K.J., McCollom, T.M., Konishi, H., and Buseck, P.R., 2003a, Seafloor bioalteration of sulfide minerals: Results from in situ incubation studies Geochimica et Cosmochimica Acta, v.67, pp. 2843-2856.

Edwards, K.J., Rogers, D.R., Wirsen, C.O., and McCollom, T.M., 2003b, Isolation and characterization of novel psychrophilic, neutrophilic, $\mathrm{Fe}$ oxidizing, chemolithoautotrophic alpha- and, gamma-Proteobacteria from the deep sea. Applied and Environmental Microbiology, v.69, pp. 2906-2913.

Ehrlich, H.L. (2005) Geomicrobiology. New York: Marcel Dekker. Inc.

Fish, S.A., Shepherd, T.J., McGenity, T.J., and Grant, W.D., 2002, Recovery of $16 \mathrm{~S}$ ribosomal RNA gene fragments from ancient halite. Nature, v.417, pp. 432-436. 
Fisk, M.R., and Giovannoni, S.J., 1999, Sources of nutrients and energy for a deep biosphere on Mars. Journal of Geophysical Research, v.104, pp. 11805-11815

Fisk, M.R., Giovannoni, S.J., and Thorseth, I.H., 1998, Alteration of oceanic volcanic glass: textural evidence of microbial activity. Science, v.281, pp 978-980.

Formolo, M.J., Lyons, T.W., Zhang, C.L., Kelley, C., Sassen, R., Horita, J., and Cole, D.R., 2004, Quantifying carbon sources in the formation of authigenic carbonates at gas hydrate sites in the Gulf of Mexico. Chemical Geology, v.205, pp. 253-264.

Franca, L., Rainey, F.A., Nobre, M.F., and Costa, M.S., 2006, Tepidicella xavieri gen. nov., sp nov., a betaproteobacterium isolated from a hot spring runoff International Journal of Systematic and Evolutionary Microbiology, v.56, pp. 907-912.

Francis, C.A., O'Mullan, G.D., and Ward, B.B., 2003, Diversity of ammonia monooxygenase (amoA) genes across environmental gradients in Chesapeake Bay sediments. Geobiology, v.1, pp. 129-140.

Francis, C.A., Roberts, K.J., Beman, J.M., Santoro, A.E., and Oakley, B.B., 2005, Ubiquity and diversity of ammonia-oxidizing archaea in water columns and sediments of the ocean. Proceedings of the National Academy of Sciences of the United States of America, v.102, pp. $14683-14688$.

Fredrickson, J.K., and Balkwill, D.L., 2006, Geomicrobial processes and biodiversity in the deep terrestrial subsurface. Geomicrobiology Journal, v.23, pp. 345-356.

Freitag, T.E., Chang, L., and Prosser, J.I., 2006, Changes in the community structure and activity of betaproteobacterial ammonia-oxidizing sediment bacteria along a freshwater-marine gradient. Environmental Microbiology, v.8, pp. 684-696.

Friedrich, C.G., 1998, Physiology and genetics of sulfur-oxidizing bacteria. Advances in Microbial Physiology, v.39, pp. 235-289.

Friedrich, C.G., Rother, D., Bardischewsky, F., Quentmeier, A., and Fischer, J., 2001, Oxidation of reduced inorganic sulfur compounds by bacteria: emergence of a common mechanism? Applied and Environmental Microbiology, v.67, pp. 2873-2882.

Friedrich, C.G., Bardischewsky, F., Rother, D., Quentmeier, A., and Fischer, J., 2005, Prokaryotic sulfur oxidation. Current Opinion in Microbiology, v.8, pp. 253-259.

Frontier, S., 1985, Diversity and structure in aquatic ecosystems: Oceanography and Marine Biology, 23: 253-312.

Furnes, H., and Staudigel, H., 1999, Biological mediation in ocean crust alteration: how deep is the deep biosphere?: Earth and Planetary Science Letters, v.166, pp. 97-103.

Furnes, H., Muehlenbachs, K., Torsvik, T., Thorseth, I.H., and Tumyr, O., 2001, Microbial fractionation of carbon isotopes in altered basaltic glass from the Atlantic Ocean, Lau Basin and Costa Rica Rift: Chemical Geology, v.173, pp. 313-330.

Galinski, E.A., and Truper, H.G., 1994, Microbial behavior in salt-stressed ecosystems: FEMS Microbiology Reviews, v.15, pp. 95-108.

Gendrin, A., Mangold, N., Bibring, J.P., Langevin, Y., Gondet, B., Poulet, F. et al., 2005, Suffates in martian layered terrains: the OMEGA/Mars Express view: Science, v.307, pp. 1587-1591.

Gihring, T.M., and Banfield, J.F., 2001, Arsenite oxidation and arsenate respiration by a new Thermus isolate: FEMS Microbiology Letters, v.204, pp. 335-340.

Gihring, T.M., Druschel, G.K., McCleskey, R.B., Hamers, R.J., and Banfield, J.F., 2001, Rapid arsenite oxidation by Thermus aquaticus and Thermus thermophilus: Field and laboratory investigations. Environmental Science and Technology, v.35, pp. 3857-3862.

Giovannoni, S.J., Britschgi, T.B., Moyer, C.L., and Field, F.G., 1990, Genetic diversity of Sargasso Sea bacterioplankton: Nature, v.345, pp. $60-65$.

Glockner, F.O., Fuchs, B.M., and Amann, R., 1999, Bacterioplankton compositions of lakes and oceans: a first comparison based on fluorescence in situ hybridization: Applied and Environmental Microbiology, v.65, pp. 3721-3726.

Greinert, J., Bohrmann, G., and Suess, E. , 2001, Gas hydrate associated carbonates and methane venting at Hydrate Ridge: classification, distribution, and origin of authigenic carbonates. In Natural Gas Hydrates: Occurrence, Distribution and Detection. Paull, C.K., and Dillon, W.P. (eds). Washington, D.C.: Geophysical Monograph, American Geophysical Union, pp. 99-113.

Hagstrom, A., Pommier, T., Rohwer, F., Simu, K., Stolte, W., Svensson, D., and Zweifel, U.L., 2002, Use of 16S Ribosomal DNA for Delineation of Marine Bacterioplankton Species: Applied and Environmental Microbiology, v.68, pp. 3628-3633.
He, J.Z., Shen, J.P., Zhang, L.M., Zhu, Y.G., Zheng, Y.M., Xu, M.G., and Di, H.J., 2007, Quantitative analyses of the abundance and composition of ammonia-oxidizing bacteria and ammonia-oxidizing archaea of a Chinese upland red soil under long-term fertilization practices: Environmental Microbiology, v.doi:10.1111/j.1462-2920.2007.01358.x, pp.

Henriques, I.S., Alves, A., Tacao, M., Almeida, A., Cunha, A., and Correia, A., 2006, Seasonal and spatial variability of free-living bacterial community composition along an estuarine gradient (Ria de Aveiro, Portugal): Estuarine Coastal and Shelf Science, v.68, pp. 139-148.

Hinrichs, K.-U., and Boetius, A., 2002, The anaerobic oxidation of methane: new insights in microbial ecology and biogeochemistry. In Ocean Marine Systems. Wefer, G., Billett, D., Hebbeln, D., Jorgensen, B.B., and Schluter, M. (eds). Berlin-Heidelberg: Springer-Verlag, pp. 457-477.

Hinrichs, K.U., Hayes, J.M., Sylva, S.P., Brewer, P.G., and DeLong, E.F., 1999, Methane-consuming archaebacteria in marine sediments: Nature, v.398, pp. 802-805.

Holm, N.G., and Andersson, E.M., 1998, Hydrothermal systems. In The Molecular Origins of Life. Brack, A. (ed): Cambridge, UK: Cambridge University Press, pp. 86-99.

Holm, N.G., and Charlou, J.-L., 2001, Initial indications of abiotic formation of hydrocarbons in the Rainbow ultramafic hydrothermal system, MidAtlantic Ridge: Earth and Planetary Science Letters, v.191, pp. 1-8.

Horita, J., and Berndt, M.E., 1999, Abiogenic methane formation and isotopic fractionation under hydrothermal conditions: Science, v.285, pp. 1055-1057.

Horsfield, B., Schenk, H.J., Zink, K., Ondrak, R., Dieckmann, V., Kallmeyer, J. et al., 2006, Living microbial ecosystems within the active zone of catagenesis: Implications for feeding the deep biosphere: Earth and Planetary Science Letters, v.246, pp. 55-69.

Hreggvidsson, G.O., Skirnisdottir, S., Smit, B., Hjorleifsdottir, S., Marteinsson, V.T., Petursdottir, S., and Kristjansson, J.K., 2006, Polyphasic analysis of Thermus isolates from geothermal areas in Iceland: Extremophiles, v.10, pp. 563-575.

Hugenholtz, P., Goebel, B.M., and Pace, N.R., 1998, Impact of culture-independent studies on the emerging phylogenetic view of bacterial diversity: Journal of Bacteriology, v.180, pp. 4765-4774.

Hughes, K.A., and Lawley, B., 2003, A novel Antarctic microbial endolithic community within gypsum crusts: Environmental Microbiology, v.5, pp. 555-565.

Inagaki, F., and Nealson, K.H., 2006, Molecular signals from ancient materials: challenges to deep-biosphere and paleoenvironmental research- A response to the comments of Sinninghe Damste and Coolen: Astrobiology, v.6, pp. 303-307.

Inagaki, F., Okada, H., Tsapin, A.I., and Nealson, K.H., 2005, The Paleome: a sedimentary genetic record of past microbial communities: Astrobiology, v.5, pp. 141-153.

Inagaki, F., Takai, K., Komatsu, T., Kanamatsu, K., Fujioka, K., and Horikoshi, K., 2001, Archaeology of Archaea: Geomicrobiological record of Pleistocene thermal events concealed in a deep-sea subseafloor environment: Extremophiles, v.5, pp. 385-392.

Inagaki, F., Nunoura, T., Nakagawa, S., Teske, A., Lever, M., Lauer, A. et al., 2006, Biogeographical distribution and diversity of microbes in methane hydrate-bearing deep marine sediments on the Pacific Ocean Margin: Proceedings of National Academy of Science, v.103, pp. 2815-2820.

Jakobsen, T.F., Kjeldsen, K.U., and Ingvorsen, 2006, Desulfohalobium utahense sp nov., a moderately halophilic, sulfate-reducing bacterium isolated from Great Salt Lake: International Journal of Systematic and Evolutionary Microbiology, v.56, pp. 2063-2069.

Jiang, H.C., Dong, H.L., Yu, B.S., Liu, X.Q., Li, Y.L., Ji, S.S., and Zhang, C.L.L., 2007, Microbial response to salinity change in Lake Chaka, a hypersaline lake on Tibetan plateau: Environmental Microbiology, 9(10), 2603-2621.

Joint, I., Henriksen, P., Garde, K., and Riemann, B., 2002, Primary production, nutrient assimilation and microzooplankton grazing along a hypersaline gradient: FEMS Microbiology Ecology, v.39, pp. 245-257.

Jorgensen, N.O., 1992, Methane-derived carbonate cementation of Holocene marine sediments from Kattegat, Denmark: Continental Shelf Research, v.12, pp. 1209-1218.

Joye, S.B., Connell, T.L., Miller, L.G., Oremland, R.S., and Jellison, R.S., 1999, Oxidation of ammonia and methane in an alkaline, saline lake: Limnology and oceanography, v.44, pp. 178-188.

Joye, S.B., Boetius, A., Orcutt, B.N., Montoya, J.P., Schulz, H.N., Erickson, M.J., and Lugo, S.K., 2004, The anaerobic oxidation of methane and sulfate reduction in sediments from Gulf of Mexico cold seeps: Chemical Geology, v.205, pp. 219-238.

Kaksonen, A.H., Spring, S., Schumann, P., Kroppenstedt, R.M., and Puhakka, J.A., 2006, Desulfotomaculum thermosubterraneum sp nov., a 
thermophilic sulfate-reducer isolated from an underground mine located in a geothermally active area: International Journal of Systematic and Evolutionary Microbiology, v.56, pp. 2603-2608.

Kaksonen, A.H., Spring, S., Schumann, P., Kroppenstedt, R.M., and Puhakka, J.A., 2007, Desulfolvirgula thermocuniculi gen. nov., sp nov., a thermophilic sulfate-reducer isolated from a geothermal underground mine in Japan: International Journal of Systematic and Evolutionary Microbiology, v.57, pp. 98-102.

Kappler, A., and Newman, D.K., 2004, Formation of Fe(III)-minerals by $\mathrm{Fe}(\mathrm{II})$-oxidizing photoautotrophic bacteria: Geochimica et Cosmochimica Acta, v.68, pp. 1217-1226.

Kelley, D.S., Karson, J.A., Blackman, D.K., Fruh-Green, G.L., Butterfield, D.A., Lilley, M.D. et al., 2001, An off-axis hydrothermal vent field near the Mid-Atlantic Ridge at 30 degrees N: Nature, v.412, pp. 145-149.

Kelley, D.S., Karson, J.A., Fruh-Green, G.L., Yoerger, D.R., Shank, T.M., Butterfield, D.A. et al., 2005, A serpentinite-hosted ecosystem: The lost city hydrothermal field: Science, v.307, pp. 1428-1434.

Kelly, D.P., Shergill, J.K., Lu, W.-P., and Wood, A.P., 1997, Oxidativemetabolism of inorganic sulfur compounds by bacteria: Antonie van Leeuwenhoek, v.71, pp. 95-107.

Kieft, T.L., and Phelps, T.J., 1997, Life in the slow lane. In The microbiology of the terrestrial subsurface. Amy, P.S., and Haldeman, D.L. (eds). Boca Raton, FL: CRC Press, pp. 137-164.

Kirchman, D.L., Dittel, A.I., Malmstrom, R.R., and Cottrell, M.T., 2005, Biogeography of major bacterial groups in the Delaware Estuary: Limnology and oceanography, v.50, pp. 1697-1706.

Kjeldsen, K.U., Loy, A., Jakobsen, T.F., Thomsen, T.R., Wagner, M., and Ingvorsen, K., 2007, Diversity of sulfate-reducing bacteria from an extreme hypersaline sediment, Great Salt Lake (Utah): FEMS Microbiology Ecology, v.60, pp. 287-298.

Kletzin, A., Urich, T., Muller, F., Bandeiras, T.M., Gomes, C.M. (2004) Dissimilatory oxidation and reduction of elemental sulfur in thermophilic archaea: Journal of Bioenergetics and Biomembrances, 36(1), 77-91.

Kminek, G., Bada, J.L., Pogliano, K., and Ward, J.F., 2003, Radiation-dependent limit for the viability of bacterial spores in halite fluid inclusions and on Mars: Radiation Research, v.159, pp. 722-729.

Kodama, Y. and K. Watanabe Isolation and characterization of a sulfur-oxidizing chemolithotroph growing on crude oil under anaerobic conditions Applied and Environmental Microbiology 2003, 69, 107-112.

Konneke, M., Bernhard, A.E., de la Torre, J.R., Walker, C.B., Waterbury, J.B., and Stahl, D.A., 2005, Isolation of an autotrophic ammonia-oxidizing marine archaeon: Nature, v.437, pp. 543-546.

Koops, H.P., Purkhold, U., Pommerening-Roser, A., Timmermann, G., and Wagner, M., 2004, The lithoautotrophic ammonia-oxidizing bacteria. In The Prokaryotes: An evolving electronic resource for the microbiological community. Release 3.13, http://link.springer-ny.com/link/service/ books/ 10125/. Springer-Verlag, New york.

Krauskopf, K.B., and Bird, D.K., 1995, Introduction to geochemistry: New York: McGraw-Hill.

Krumholz, L.R., 2000, Microbial communities in the deep subsurface: Hydrogeology Journal, v.8, pp. 4-10.

Krumholz, L.R., McKinley, J.P., Ulrich, F.A., and Suflita, J.M., 1997, Confined subsurface microbial communities in Cretaceous rock: Nature, v.386, pp. 64-66.

Krumholz, L.R., Harris, S.H., Tay, S.T., and Suflita, J.M., 1999, Characterization of two subsurface H-2-utilizing bacteria, Desulfomicrobium hypogeium sp nov and Acetobacterium psammolithicum sp nov., and their ecological roles: Applied and Environmental Microbiology, v.65, pp. 2300-2306.

Kulm, L.D., and Suess, E., 1990, Relationship between carbonate deposits and fluid venting: Oregon accretionary prism: Journal of Geophysical Research, v.95, pp. 8899-8915.

Kuypers, M.M.M., Blokker, P., Erbacher, J., Kinkel, H., Pancost, R.D., Schouten, S., and Sinninghe Damsté, J.S., 2001, Massive expansion of marine archaea during a mid-Cretaceous oceanic anoxic event: Science, v.293, pp. 92-94.

Kuypers, M.M.M., Blokker, P., Hopmans, E.C., Kinkel, H., Pancost, R.D., Schouten, S., and Sinninghe Damsté, J.S., 2002, Archaeal remains dominate marine organic matter from the early Albian Oceanic Anoxic Event 1b: Palaeogeography, Palaeoclimatology, Palaeoecology, v.185, pp. 211-234.

Land, L.S., 1998, Failure to precipitate dolomite at $25^{\circ} \mathrm{C}$ from dilute solutions despite 1000 -fold oversaturation after 32 years: Aquatic Geochemistry, v.4, pp. 361-368.

Langenheder, S., Kisand, V., Wikner, J., and Tranvik, L.J., 2003, Salinity as a structuring factor for the composition and performance of bacterio- plankton degrading riverine: DOC FEMS Microbiology Ecology, v.45, pp. 189-202.

Langevin, Y., Poulet, F., Bibring, J.P., and Gondet, B., 2005, Sulfates in the north polar region of Mars detected by OMEGA/Mars express: Science, v.307, pp. 1584-1586.

Leininger, S., Urich, T., Schloter, M., Schwark, L., Qi, J., Nicol, G.W. et al., 2006, Archaea predominate among ammonia-oxidizing prokaryotes in soils: Nature, v.442, pp. 806-809.

Lin, L.H., Hall, J., Lippmann-Pipke, J., Ward, J.A., Lollar, B.S., DeFlaun, M. et al., 2005, Radiolytic H-2 in continental crust: Nuclear power for deep subsurface microbial communities: Geochemistry, Geophysics, Geosystems, v.6, pp. Q07003.

Lin, L.H., P.L. Wang, D. Rumble, J. Lippmann-Pipke, E. Boice, L.M. Pratt, B.S. Lollar, E.L. Brodie, T.C. Hazen, G.L. Andersen, T.Z. DeSantis, D.P. Moser, D. Kershaw, and T.C. Onstott, 2007, Long-term sustainability of a high-energy, low-diversity crustal biome: Science, 314, 479-482.

Lindahl, T., 1993, Instability and decay of the primary structure of DNA Nature, v.362, pp. 709-715.

Lollar, B.S., Lacrampe-Couloume, G., Slater, G., Ward, J.A., Moser, D.P., Gihring, T.M. et al., 2006, Unravelling abiogenic and biogenic sources of methane in the Earth's deep subsurface: Chemical Geology, v.226, pp. 328-339.

MacGregor, B.J., Moser, D.P., Alm, E.W., Nealson, K.H., and Stahl, D.A., 1997, Crenarchaeota in Lake Michigan Sediment: Applied and Environmental Microbiology, v.63, pp. 1178-1181.

MacGregor, B.J., Moser, D.P., Baker, B.J., Alm, E.W., Maurer, M., Nealson, K.H., and Stahl, D.A., 2001, Seasonal and spatial variability in Lake Michigan sediment small-subunit rRNA concentrations: Applied and Environmental Microbiology, v.67, pp. 3908-3922.

Madigan, M.T., Martinko, J.M., and Parker, J., 2004, Brock Biology of Microorganisms. Upper Saddle River, NJ: Prentice Hall.

Magot, M., B. Ollivier, and B.K.C. Patel, 2004, Microbiology of petroleum reservoirs. Antonie van Leeuwenhoek, 77, 103-116.

Matsumoto, R., 1990, Vuggy carbonate crust formed by hydrocarbon seepage on the continental shelf of Baffin Island, northeast Canada: Geochemical Journal, v.24, pp. 143-158.

Maturrano, L., Santos, F., Rossello-Mora, R., and Anton, J., 2006, Microbial diversity in Maras salterns, a hypersaline environment in the Peruvian Andes: Applied and Environmental Microbiology, v.72, pp. 3887-3895.

Mazzullo, S.J., 2000, Organogenic Dolomitization in peritidal to deep-sea sediments: Journal of Sedimentary Research, v.70, pp. 10-23.

McCollom, T.M., and Seewald, J.S., 2001, A reassessment of the potential for reduction of dissolved $\mathrm{CO}_{2}$ to hydrocarbons during serpentinization of olivine: Geochimica et Cosmochimica Acta, v.65, pp. 3769-3778.

McCollom, T.M., and Seewald, J.S., 2003, Experimental constraints on the hydrothermal reactivity of organic acids and acid anions: I. Formic acid and formate: Geochimica et Cosmochimica Acta, v.67, pp. 3625-3644.

McCollom, T.M., and Seewald, J.S., 2006, Carbon isotope composition of organic compounds produced by abiotic synthesis under hydrothermal conditions: Earth and Planetary Science Letters, v.243, pp. 74-84.

McCollom, T.M., Ritter, G., and Simoneit, B.R.T., 1999, Lipid synthesis under hydrothermal conditions by Fischer-Tropsch-type reactions: Origins of life and evolution of the bipsphere, v.29, pp. 153-166.

McMahon, P., B., 2001, Aquifer/aquitard interfaces: mixing zones that enhance biogeochemical reactions: Hydrogeology Journal, v.9, pp. 34-43.

McMahon, P.B., and Chapelle, F.H., 1991, Microbial production of organic acids in aquitard sediments and its role in aquifer geochemistry: Nature, v.349, pp. 233-235.

Michaelis, W., Seifert, R., Nauhaus, K., Treude, T., Thiel, V., Blumenberg, M. et al., 2002, Microbial reefs in the Black Sea fueled by anaerobic oxidation of methane: Science, v.297, pp. 1013-1015.

Miroshnichenko, M.L., and Bonch-Osmolovskaya, E.A., 2006, Recent developments in the thermophilic microbiology of deep-sea hydrothermal vents: Extremophiles, v.10, pp. 85-96.

Moore, T.S., Murray, R.W., Kurtz, A.C., and Schrag, D.P., 2004, Anaerobic methane oxidation and the formation of dolomite: Earth and Planetary Science Letters, v.229, pp. 141-154.

Nagy, M.L., Pe'rez, A., and Garcia-Pichel, F., 2005, The prokaryotic diversity of biological soil crusts in the Sonoran Desert (Organ Pipe Cactus National Monument, AZ): FEMS Microbiology Ecology, v.54, pp. 233-245.

Nauhaus, K., Boetius, A., Kruger, M., and Widdel, F., 2002, In vitro demonstration of anaerobic oxidation of methane coupled to sulphate reduction in sediment from a marine gas hydrate area: Environmental Microbiology, v.4, pp. 296-305. 
Navarro-Gonzalez, R., Rainey, F.A., Molina, P., Bagaley, D.R., Hollen, B.J., de la Rosa, J. et al., 2003, Mars-like soils in the Atacama Desert, Chile, and the dry limit of microbial life: Science, v.302, pp. 1018-1021.

Nazina, T.N., Kosareva, I.M., Davidov, A.S., Tourova, T.P., Novikova, E.V ., Khafizov, R.R., and Poltaraus, A.B., 2000, Physicochemical and microbiological characteristics of groundwater from observation wells of a deep radioactive liquid waste repository: Microbiology, v.69, pp. 89-95.

Nealson, K.H., and Cox, B.L., 2002, Microbial metal-ion reduction and Mars: extraterrestrial expectations?: Current Opinion in Microbiology, v.5, pp. 296-300.

Nealson, K.H., Inagaki, F., and Takai, K., 2005, Hydrogen-driven subsurface lithoautotrophic microbial ecosystems (SLiMEs): do they exist and why should we care?: Trends in Microbiology, v.13, pp. 405-410.

Nicol, G.W., and Schleper, C., 2006, Ammonia-oxidising Crenarchaeota: important players in the nitrogen cycle? Trends in Microbiology, v.14, pp. 207-212.

Orcutt, B.N., Boetius, A., Lugo, S.K., MacDonald, I.R., Samarkin, V.A., and Joye, S.B., 2004, Life at the edge of methane ice: methane and sulfur cycling in Gulf of Mexico gas hydrates: Chemical Geology, v.205, pp. 239-251.

Oren, A., 1993, Ecology of extremely halophilic microorganisms. In The biology of halophilic bacteria. Vreeland, R.H., and Hochstein, L.I. (eds). Boca Raton: FL CRC Press, pp. 25-53.

Oren, A., 1999a, Microbiology and Biogeochemistry of Hypersaline Environments: New York: CRC Press.

Oren, A , 1999b, The enigma of square and triangular bacteria. In Enigmatic microorganisms and life in extreme environments. Seckbach, J. (ed) Kluwer Academic Publishers: Dordrecht, pp. 337-355.

Oren, A., 2001, The bioenergetic basis for the decrease in metabolic diversity at increasing salt concentrations: implications for the functioning of salt lake ecosystems: Hydrobiologia, v.466, pp. 61-72.

Oren, A., 2002a, Halophilic microorganisms and their environments. Dordrecht; Boston: Kluwer Academic.

Oren, A., 2002b, Diversity of halophilic microorganisms: Environments, phylogeny, physiology, and applications: Journal of Industrial Microbiology \& Biotechnology, v.28, pp. 56-63.

Orphan, V.J., Taylor, L.T., Hafenbradl, D., and Delong, E.F., 2000, Culturedependent and culture-independent characterization of microbial assemblages associated with high-temperature petroleum reservoirs: Applied and Environmental Microbiology, v.66, pp. 700-711.

Orphan, V.J., House, C.H., Hinrichs, K.U., McKeegan, K.D., and DeLong, E.F., 2001, Methane-consuming archaea revealed by directly coupled isotopic and phylogenetic analysis: Science, v.293, pp. 484-487.

Pace, N.R., 1997, A molecular view of microbial diversity and the biosphere: Science, v.276, pp. 734-740.

Parkes, R.J., Cragg, B.A., and Wellsbury, P., 2000, Recent studied on bacterial population and processes in subseafloor sediments: a review: Hydrogeology Journal, v.8, pp. 11-28.

Parkes, R.J., Cragg, B.A., Bale, S.J., Getliff, J.M., Goodman, K., Rochelle, P.A. et al., 1994, Deep bacterial biosphere in Pacific Ocean sediments: Nature, v.371, pp. 410-413.

Peckmann, J., and Thiel, V., 2004, Carbon cycling at ancient methane-seeps: Chemical Geology, v.205, pp. 443-467.

Peckmann, J., Gischler, E., Oschmann, W., and Reitner, J., 2001, An early carboniferous seep community and hydrocarbon-derived carbonates from the Harz Mountains, Germany: Geology, v.29, pp. 271-274.

Peckmann, J., V.Thiel, Michaelis, W., Clari, P., Gaillard, C., Martire, L., and J.Reitner, 1999, Cold seep deposits of Beauvoisin (Oxfordian; southeastern France) and Marmorito (Miocene; northern Itlay): microbially induced authigenic carbonates: International Journal of Earth Sciences, v.88, pp. $60-75$.

Pedersen, K., 1997, Microbial life in deep granitic rock: FEMS Microbiology Reviews, v.20, pp. 399-414.

Pedersen, K., 2000, Exploration of deep intraterrestrial microbial life: current perspectives: FEMS Microbiology Letters, v.185, pp. 9-16.

Pedersen, K., 2001, Diversity and activity of microorganisms in deep igneous rock aquifers of the fennoscandian shield. In Subsurface Microgeobiology and Biogeochemistry. Frederick, J.F., and Fletcher, M. (eds): New York: Wiley-Liss, pp. 97-139.

Pedros-Alio, C., 2006, Marine microbial diversity: can it be determined?: Trends in Microbiology, v.14, pp. 257-263.

Phillips, C.J., Smith, Z., Embley, T.M., and Prosser, J.I., 1999, Phylogenetic differences between particle-associated and planktonic ammonia-oxidizing bacteria of the beta subdivision of the class Proteobacteria in the northwestern Mediterranean Sea: Appl Environ Microbiol 65: 779-786.

Pierre, C., and Rouchy, J.M., 2004, Isotopic compositions of diagenetic dolomites in the Tortonian marls of the western Mediterranean margins: evidence of the past gas hydrate formation and dissociation: Chemical Geology, v.205, pp. 469-484.

Pitonzo, B.J., Amy, P.S., and Rudin, M., 1999, Effect of gamma radiation on native endolithic microorganisms from a radioactive waste deposit site: Radiation Research, v.152, pp. 64-70.

Pommier, T., Pinhassi, J., and Hagstrom, A., 2005, Biogeographic analysis of ribosomal RNA clusters from marine bacterioplankton: Aquatic Microbial Ecology, v.41, pp. 79-89.

Pronk, J.T., Meulenberg, R., Hazeu, W., Bos, P., and Kuenen, J.G., 1990, Oxidation of reduced inorganic sulfur-compounds by acidophilic Thiobacilli: FEMS Microbiology Reviews, v.75, pp. 293-306.

Prosser, J.I., and Embley, T.M., 2002, Cultivation-based and molecular approaches to characterisation of terrestrial and aquatic nitrifiers: Antonie van Leeuwenhoek, v.81, pp. 165-179.

Rainey, F.A., Ray, K., Ferreira, M., Gatz, B.Z., Nobre, M.F., Bagaley, D. et al., 2005, Extensive Diversity of Ionizing-Radiation-Resistant Bacteria Recovered from a Sonoran Desert Soil and Description of Nine New Species of the Genus Deinococcus Obtained from a Single Soil Sample: Applied and Environmental Microbiology, v.71, pp. 5225-5235.

Reysenbach, A.-L., 2001a, Thermotogales. In Bergey's Manual of systematic bacteriology. Boone, D.R., and Garrity, G.M.e. (eds): Berlin Heidelberg New York: Springer, pp. 369-387.

Reysenbach, A.L., 2001b, Aquificales. In Bergey's manual of systematic bacteriology. Boone, D.R., and Garrity, G.M.e. (eds):Berlin Heidelberg New York: Springer, pp. 369-387.

Roberts, H.H., and Aharon, P., 1994, Hydrocarbon-derived carbonate buildups of the northern Gulf-of-Mexico continental slope - a review of submersible investigations: Geo-Marine Letters, v.14, pp. 135-148.

Roberts, J.A., Bennett, P.C., Gonzalez, L.A., Macpherson, G.L., and Milliken, K.L., 2004, Microbial precipitation of dolomite in methanogenic groundwater: Geology, v.32, pp. 277-280.

Robertson, L.A., and Kuenen, J.G., 1999,. The colorless sulfur bacteria. URL www.link.springer-ny.com/link/service/books/10125, Release 3.05/21/ 1999.

Rodriguez, N.M., Paull, C.K., and Borowski, W.S., 2000, Zonation of authigenic carbonates within gas-hydrate bearing sedimentary sections on the Blake Ridge: offshore southeastern North America. In Proceedings of Ocean Drilling Program: Scientific Research. Paull, C.K., Matsumoto, R., Wallace, P.J., and Dillon, W.P. (eds), pp. 301-312.

Rothschild, L.J., and Mancinelli, R.L., 2001, Life in extreme environments: Nature, v.409, pp. 1092-1101.

Rothschild, L.J., Giver, L.J., White, M.R., and Mancinelli, R.L., 1994, Metabolic-activity of microorganisms in evaporites: Journal of Phycology, v.30, pp. 431-438.

Russell, M.J., 2003, The importance of being alkaline: Science, v.302, pp. $580-581$.

Russell, M.J., Daia, D.E., and Hall, A.J., 1998, The emergence of life from FeS bubbles at alkaline hot springs in an acid ocean. In Thermophiles: The Keys to Molecular Evolution and the Origin of Life? J. Wiegel and M. W. W. Adams (ed): Taylor \& Francis, pp. 77-126.

Sample, J.C., and Reid, M.R., 1998, Contrasting hydrogeologic regimes along strike-slip and thrust faults in the Oregon convergent margin: Evidence from the chemistry of syntectonic carbonate cements and veins: Geological Society of America Bulletin, v.110, pp. 48-59.

Sanchez-Roman, M., McKenzie, J.A., Vasconcelos, C., and Rivadeneyra, M., 2005, Bacterially Induced Dolomite Formation in the Presence of Sulfate Ions under Aerobic Conditions. In 2005 AGU Fall meeting. San Francisco.

Sassen, R., Roberts, H.H., Carney, R., Milkov, A.V., DeFreitas, D.A., Lanoil, B., and Zhang, C.L., 2004, Free hydrocarbon gas, gas hydrate, and authigenic minerals in chemosynthetic communities of the northern Gulf of Mexico continental slope: relation to microbial processes: Chemical Geology, v.205, pp. 195-217.

Scappini, F., Casedi, F., Zamboni, R., Franchi, M., Gallori, E., and Monti, S., 2004, Protective effect of clay minerals on adsorbed nucleic acid against UV radiation: possible role in the origin of life: International Journal of Astrobiology, v.3, pp. 17-19.

Schippers, A., Neretin, L.N., Kallmeyer, J., Ferdelman, T.G., Cragg, B.A., Parkes, R.J., and Jorgensen, B.B., 2005, Prokaryotic cells of the deep subseafloor biosphere identified as living bacteria: Nature, v.433, pp. $861-864$

Schleper, C., Jurgens, G., and Jonuscheit, M., 2005, Genomic studies of uncultivated archaea: Nature Reviews Microbiology, v.3, pp. 479-488.

Schlesinger, W.H., Pippen, J.S., Wallenstein, M.D., Hofmockel, K.S., Klepeis, D.M., and Mahall, B.E., 2003, Community composition and photosynthesis by photoautotrophs under quartz pebbles, southern Mojave Desert: Ecology, v.84, pp. 3222-3231. 
Schweitzer, B., Huber, I., Amann, R., Ludwig, W., and Simon, M., 2001, alpha- and beta-Proteobacteria control the consumption and release of amino acids on lake snow aggregates: Applied and Environmental Microbiology, v.67, pp. 632-645.

Selje, N., and Simon, M., 2003, Composition and dynamics of particle-associated and free-living bacterial communities in the Weser estuary, Germany: Aquatic Microbial Ecology, v.30, pp. 221-237.

Sharma, A., Scott, J.H., Cody, G.D., Fogel, M.L., Hazen, R.M., Hemley, R.J., and Huntress, W.T., 2002, Microbial Activity at Gigapascal Pressures: Science, v.295, pp. 1514-1516.

Shock, E.L., 1990, Geochemical constraints on the origin of organic compounds in hydrothermal systems. Origins of life and evolution of the bipsphere, v.20, pp. 331-367.

Shock, E.L., 1997, High-temperature Life Without Photosynthesis as a Model for Mars: Journal of Geophysical Research, v.102, pp. 23687-23694.

Shock, E.L., and Schulte, M.D., 1998, Organic synthesis during fluid mixing in hydrothermal systems: Journal of Geophysical Research, v.103, pp. 28513-28517.

Sinninghe Damsté, J.S., and Coolen, M.J.L., 2006, Fossil DNA in Cretaceous black shales: myth or reality: Astrobiology, v.6, pp. 299-302.

Skirnisdottir, S., Hreggvidsson, G.O., Holst, O., and Kristjansson, J.K., 2001, Isolation and characterization of a mixotrophic sulfur-oxidizing Thermus scotoductus Extremephiles, v.5, pp. 45-51.

Sleep, N.H., Meibom, A., Fridriksson, T., Coleman, R.G., and Bird, D.K., 2004, H2-rich fluids from serpentinization: Geochemical and biotic implications: Proceedings of National Academy of Science of the USA, v.101, pp. 12818-12823.

Slobodkin, A.I., 2005, Thermophilic microbial metal reduction: Microbiology, 74(5), 501-504.

Sorensen, K.B., Canfield, D.E., and Oren, A., 2004, Salinity responses of benthic microbial communities in a solar saltern (Eilat, Israel): Applied and Environmental Microbiology, v.70, pp. 1608-1616.

Sorensen, K.B., Canfield, D.E., Teske, A.P., and Oren, A., 2005, Community composition of a hypersaline endoevaporitic microbial mat: Applied and Environmental Microbiology, v.71, pp. 7352-7365.

Sorokin, D.Y., and Kuenen, J.G., 2005, Chemolithotrophic halo alkaliphiles from soda lakes: FEMS Microbiology Ecology, v.52, pp. 287-295.

Sorokin, D.Y., Antipov, A.N., and Kuenen, J.G., 2003, Complete denitrification in coculture of obligately chemolithoautotrophic haloalkaliphilic sulfur-oxidizing bacteria from a hypersaline soda lake: Archives of Microbiology, v.180, pp. 127-133.

Sorokin, D.Y., Tourova, T.P., Lysenko, A.M., and Muyzer, G., 2006a, Diversity of culturable halophilic sulfur-oxidizing bacteria in hypersaline habitats: Microbiology, v.152, pp. 3013-3023.

Sorokin, D.Y., Tourova, T.P., Kolganova, T.V., Spiridonova, E.M., Berg, I.A., and Muyzer, G., 2006b, Thiomicrospira halophila sp nov., a moderately halophilic, obligately chemolithoautotrophic, sulfur-oxidizing bacterium from hypersaline lakes: International Journal of Systematic and Evolutionary Microbiology, v.56, pp. 2375-2380.

Squyres, S.W., Grotzinger, J.P., Arvidson, R.E., Bell, J.F., Calvin, W., Christensen, P.R. et al., 2004, In situ evidence for an ancient aqueous environment at Meridiani Planum, Mars:Science, v.306, pp. 1709-1714.

Stakes, D.S., Orange, D., Paduan, J.B., Salamy, K.A., and Maher, N., 1999 Cold-seeps and authigenic carbonate formation in Monterey Bay, California: Marine Geology, v.159, pp. 93-109.

Staudigel, H., Furnes, H., Banerjee, N.R., Dilek, Y., and Muehlenbachs, K., 2006, Microbes and volcanoes: a tale of the oceans, ophiolites, and greenstone belts: GSA Today, v.16, pp. 4-10.

Stevens, T.O., and McKinley, J.P., 1995, Lithoautotrophic microbial ecosystems in deep basalt aquifers: Science, v.270, pp. 450-454.

Stougaard, P., Jørgensen, F., Johnsen, M.G., and Hansen, O.C., 2002, Microbial diversity in ikaite tufa columns: an alkaline, cold ecological niche in Greenland: Environmental Microbiology, v.4, pp. 487-493.

Takai, K., and Horikoshi, K., 1999, Genetic diversity of archaea in deep-sea hydrothermal vent environments: Genetics, v.152, pp. 1285-1297.

Takai, K., Komatsu, T., and Horikoshi, K., 2001, Hydrogenobacter subterraneus sp nov., an extremely thermophilic, heterotrophic bacterium unable to grow on hydrogen gas, from deep subsurface geothermal water: International Journal of Systematic and Evolutionary Microbiology, v.51, pp. 1425-1435.

Takai, K., Gamo, T., Tsunogai, U., Nakayama, N., Hirayama, H., Nealson, K.H., and Horikoshi, K., 2004, Geochemical and microbiological evidence for a hydrogen-based, hyperthermophilic subsurface lithoautotrophic microbial ecosystem (HyperSLiME) beneath an active deep-sea hydrothermal field: Extremophiles, v.8, pp. 269-282.
Templeton, A.S., Staudigel, H., and Tebo, B.M., 2005, Diverse Mn(II)-oxidizing bacteria isolated from submarine basalts at Loihi Seamount: Geomicrobiology Journal, v.22, pp. 127-139.

Terzi, C., Aharon, P., Lucchi, F.R., and Vai, G.B., 1994, Petrography and stable-isotope aspects of cold vent activity imprinted on Miocene age calcari-a-lucina from Tuscan and Romagna Apennines, Italy: Geo-Marine Letters, v.14, pp. 177-184.

Teske, A., Dhillon, A., and Sogin, M.L., 2003, Genomic markers of ancient anaerobic microbial pathways: sulfate reduction, methanogenesis, and methane oxidation: Biology Bulletin, v.204, pp. 186-191.

Teske, A., Hinrichs, K.-U., Edgcomb, V., Gomez, A.d.V., Kysela, D., Sylva, S.P. et al., 2002, Microbial diversity of hydrothermal sediments in the Guaymas Basin: evidence for anaerobic methanotrophic communities: Applied and Environmental Microbiology, v.68, pp. 1994-2007.

Teske, A.P., 2005, The deep subsurface biosphere is alive and well: Trends in Microbiology, v.13, pp. 402-404.

Teske, A.P., 2006, Microbial communities of deep marine subsurface sediments: Molecular and cultivation surveys: Geomicrobiology Journal, v.23, pp. 357-368.

Thevenieau, F., Fardeau, M., L., Ollivier, B., Joulian, C., and Baena, S., 2007, Desulfomicrobium thermophilum sp nov., a novel thermophilic sulphate-reducing bacterium isolated from a terrestrial hot spring in Colombia: Extremophiles, v.11, pp. 295-303.

Thomsen, T.R., Finster, K., and Ramsing, N.B., 2001, Biogeochemical and molecular signatures of anaerobic methane oxidation in a marine sediment: Applied and Environmental Microbiology, v.67, pp. 1646-1656.

Thorseth, I.H., Torsvik, T., Furnes, H., and Muehlenbachs, K., 1995, Microbes play an important role in the alteration of oceanic crust: Chemical Geology, v.126, pp. 137-146.

Treusch, A.H., Leininger, S., Kletzin, A., Schuster, S.C., Klenk, H.P., and Schleper, C., 2005, Novel genes for nitrite reductase and Amo-related proteins indicate a role of uncultivated mesophilic crenarchaeota in nitrogen cycling: Environmental Microbiology, v.7, pp. 1985-1995.

Tsikos, H., Karakitsios, V., van Breugel, Y., Walsworth-Bell, B., Petrizzo, M.R., Bombardiere, L. et al., 2004, Organic-carbon deposition in the Cretaceous of the Ionian Basin, NW-Greece: the Paquier Event (OAE 1b) revisited: Geological Magazine, v.141, pp. 401-416.

Urakawa, H., Kurata, S., Fujiwara, T., Kuroiwa, D., Maki, H., Kawabata, S. et al., 2006, Characterization and quantification of ammonia-oxidizing bacteria in eutrophic coastal marine sediments using polyphasic molecular approaches and immunofluorescence staining: Environmental Microbiology, v.8, pp. 787-803.

Valentine, D.L., and Reeburgh, W.S., 2000, New perspectives on anaerobic methane oxidation: Environmental Microbiology, v.2, pp. 477-484.

Van Hamme, J.D., A. Singh, and O.P. Ward Recent advances in petroleum microbiology: Microbiology and Molecular Biology Reviews 2003, 67 503-549.

Vargas, M., Kashefi, K., Blunt-Harris, E.L., and Lovley, D.R., 1998, Microbiological evidence for Fe(III) reduction on early Earth: Nature, v.395, pp. 65-67.

Vasconcelos, C., and McKenzie, J.A., 1997, Microbial mediation of modern dolomite precipitation and diagenesis under anoxic conditions (Lagoa Vermelha, Rio de Janeiro, Brazil): Journal of Sedimentary Research, v.67, pp. 378-390.

Vasconcelos, C., McKenzie, J.A., Bernasconi, S., Grujic, D., and Tien, A.J., 1995, Microbial mediation as a possible mechanism for natural dolomite formation at low temperature: Nature, v.377, pp. 220-222.

Venter, J.C., Remington, K., Heidelberg, J.F., Halpern, A.L., Rusch, D., Eisen, J.A. et al., 2004, Environmental genome shotgun sequencing of the Sargasso Sea: Science, v.304, pp. 66-74.

Ventosa, A., 2004, Halophilic microorganisms: Berlin, New York: Springer.

Ventosa, A., Nieto, J. J. \& Oren, A., 1998, Biology of moderately halophilic aerobic bacteria: Microbiology and Molecular Biology Reviews, v.62, pp. 504-544.

vonRad, U., Rosch, H., Berner, U., Geyh, M., Marchig, V., and Schulz, H., 1996, Authigenic carbonates derived from oxidized methane vented from the Makran accretionary prism off Pakistan:Marine Geology, v.136, pp. 55-77.

Voytek, M.A., Priscu, J.C., and Ward, B.B., 1999, The distribution and relative abundance of ammonia-oxidizing bacteria in lakes of the McMurdo Dry Valley, Antarctica: Hydrobiologia, v.401, pp. 113-130.

Vreeland, R.H., and Hochstein, L.I., 1993, The biology of halophilic bacteria: Boca Raton, FL: CRC Press.

Vreeland, R.H., Rosenzweig, W.D., and Powers, D.W., 2000, Isolation of a 250 million-year-old halotolerant bacterium from a primary salt crystal: Nature, pp. 897-900. 
Walsh, D.A., Papke, R.T., and Doolittle, W.F., 2005, Archaeal diversity along a soil salinity gradient prone to disturbance: Environmental Microbiology, v.7, pp. 1655-1666.

Wang, C.S., Hu, X.M., Sarti, M., Scott, R.W., and Li, X.H., 2005, Upper Cretaceous oceanic red beds in southern Tibet: a major change from anoxic to oxic, deep-sea environments: Cretaceous Research, v.26, pp. 21-32.

Ward, B.B., Martino, D.P., Diaz, M.C., and Joye, S.B., 2000, Analysis of ammonia-oxidizing bacteria from hypersaline Mono Lake, California, on the basis of 16S rRNA sequences: Applied and Environmental Microbiology, v.66, pp. 2873-2881.

Ward, J.A., Slater, G.F., Moser, D.P., Lin, L.H., Lacrampe-Couloume, G., Bonin, A.S. et al., 2004, Microbial hydrocarbon gases in the Witwatersrand Basin, South Africa: Implications for the deep biosphere: Geochimica et Cosmochimica Acta, v.68, pp. 3239-3250.

Warren-Rhodes, K.A., Rhodes, K.L., Boyle, L., Pointing, S.B., Chen, Y. Liu, S.J. et al., 2007, Cyanobacterial ecologyacross environmental gradients and spatial scales in China's hot and cold deserts: FEMS Microbiology Ecology, v.61, pp. 470-482.

Warren-Rhodes, K.A., Rhodes, K.L., Pointing, S.B., WEwing, S., Lacap, D.C., Gomez-Silva, B. et al., 2006, Hypolithic cyanobacteria, dry limit of photosynthetic and microbial community ecology in the hyperarid Atacama Desert: Microbial Ecology, 52(3), 389-398.

Warthmann, R., Vasconcelos, C., Sass, H., and McKenzie, J.A., 2005, Desulfovibrio brasiliensis sp. nov., a moderate halophilic sulfate-reducing bacterium from Lagoa Vermelha (Brazil) mediating dolomite formation: Extremephiles, v.9, pp. 255-261.

Warthmann, R., van Lith, Y., Vasconcelos, C., McKenzie, J.A., and Karpoff, A.M., 2000, Bacterially induced dolomite precipitation in anoxic culture experiments: Geology, v.28, pp. 1091-1094.

Webster, G., Parkes, R.J., Fry, J.C., and Weigthman, A.J., 2004, Widespread occurrence of a novel division of bacteria identified by $16 \mathrm{~S}$ rRNA gene sequences originally found in deep marine sediments: Applied and Environmental Microbiology, v.70, pp. 5708-5713.

Weidler, G.W., Dornmayr-Pfaffenhuemer, M., Gerbl, F.W., Heinen, W., and Stan-Lotter, H., 2007, Communities of Archaea and Bacteria in a subsurface radioactive thermal spring in the Austrian central Alps, and evidence of ammonia-oxidizing Crenarchaeota: Applied and Environmental Microbiology, 73, 259-270.

Welsh, D.T., Lindsay, Y.E., Caumette, P., Herbert, R.A., and Hannan, J. 1996, Identification of trehalose and glycine betaine as compatible solutes in the moderately halophilic sulfate reducing bacterium Desulfovibrio halophilus: FEMS Microbiology Letters, v.140, pp. 203-207.

Whitman, W.B., Coleman, D.C., and Wiebe, W.J., 1998, Prokaryotes: the unseen majority: Proceedings of National Academy of Science of the USA, v.95, pp. 6578-6583.

Wierzchos, J., Ascaso, C., and McKay, C.P., 2006, Endolithic cyanobacteria in halite rocks from the hyperarid core of the Atacama desert: Astrobiology, v.6, pp. 415-422.

Wilcock, W.S.D., Delong, E.F., Kelley, D.S., Baross, J.A., and Cary, S.C. 2004, The Subseafloor Biosphere at Mid-Ocean Ridges. Washington, DC: American Geophysical Union.

Wright, D., 1999, The role of sulphate-reducing bacteria and cyanobacteria in dolomite formation in distal ephemeral lakes of the Coorong region, South Australia: Sedimentary Geology, v.126, pp. 147-157.

Wright, D.T., and Oren, A., 2005, Nonphotosynthetic bacteria and the formation of carbonates and evaporites through time: Geomicrobiology Journal, v.22, pp. 27-53.

Wu, Q.L., Zwart, G., Schauer, M., Kamst-van Agterveld, M.P., and Hahn, M.W., 2006, Bacterioplankton community composition along a salinity gradient of sixteen high-mountain lakes located on the Tibetan Plateau, China: Applied and Environmental Microbiology, v.72, pp. 5478-5485.

Wuchter, C., Abbas, B., Coolen, M.J.L., Herfort, L., van Bleijswijk, J., Timmers, P. et al., 2006, Archaeal nitrification in the ocean: Proceedings of National Academy of Sciences of the United States of America, v.103, pp. 12317-12322.

Wynn-Williams, D.D., 2000, Cyanobacteria in deserts-life at the limit ? In The Ecology of Cyanobacteria-Their Diversity in Time and Space. Whitton, B.A., and M.Potts (eds): Dordrecht, The Netherlands: Kluwer Academic Publishers, pp. 341-366.

Zavarzina, D.G., Sokolova, T.G., Tourova, T.P., Chernyh, N.A., Kostrikina, N.A., and Bonch-Osmolovskaya, E.A., 2007, Thermincola ferriacetica sp nov., a new anaerobic, thermophilic, facultatively chemolithoautotrophic bacterium capable of dissimilatory $\mathrm{Fe}$ (III) reduction: Extremophiles v.11, pp. 1-7.

Zhang, Y., Jiao, N.Z., Cottrell, M.T., and Kirchman, D.L., 2006, Contribution of major bacterial groups to bacterial biomass production along a salinity gradient in the South China Sea: Aquatic Microbial Ecology, v.43, pp. 233-241.

Zhang, Y., Ruan, X.H., Camp, H.J.M.O.d., Smits, T.J.M., Jetten, M.S.M., and Schmid, M.C., 2007, Diversity and abundance of aerobic and anaerobic ammonium-oxidizing bacteria in freshwater sediments of the Xinyi River (China): Environmental Microbiology, v.doi:10.1111/j.14622920. 2007. 01357.x.

Zolotov, M.Y., and Shock, E.L., 2004, A model for low-temperature biogeochemistry of sulfur, carbon, and iron on Europa: Journal of Geophysical Research-Planets, v.109 E6), Art. No, E06003.

Hailiang Dong is a professor of Geomicrobiology, Mineralogy, and Geochemistry at Miami University, Oxford, OH, USA and an adjunct professor at China University of Geosciences in Beijing (CUGB). He is Director of the Geo-microbiology Laboratory at CUGB. His main interests are mineral-microbe interactions, life in extreme environments, and environ-mental remediation of contaminated ground-water and soils. He has published over 60 research articles, and has been a principle investigator for nearly 20 research projects. He has been an associate editor for several journals, and has served on proposal review panels for NSF, Department of Energy, and NASA.

Bingson $\mathbf{Y u}$ is a professor of Sedimentology, Geomicrobiology and Geochemistry in China University of Geosciences in Beijing. He is Associate Director of Geomicrobiology Laboratory, CUGB. His research interests include petroliferous sedimentology, petroleum geology, the relationship between microbial activity and the preservation of organic matter in sediments, the action of microbial on the dolomite formation.
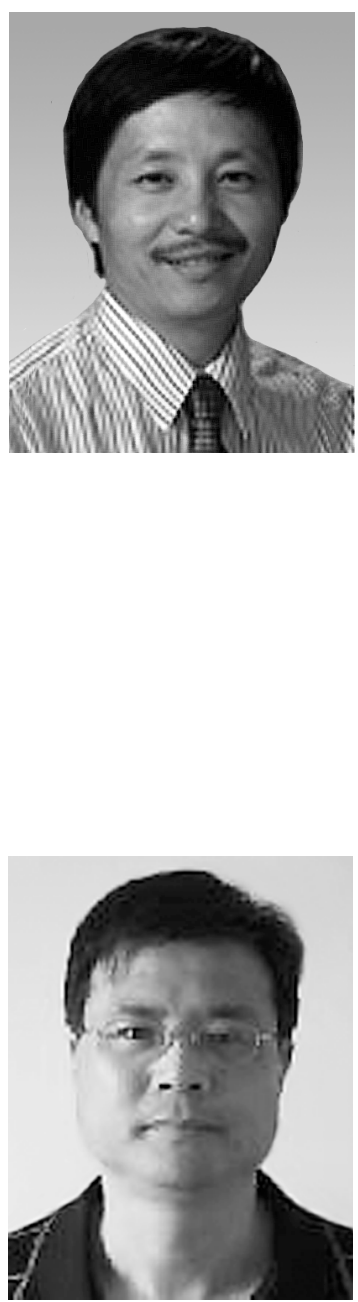